\title{
The Molecular Mechanisms by Which Vitamin D Prevents Insulin Resistance and Associated Disorders
}

\author{
Izabela Szymczak-Pajor ${ }^{1}$, Józef Drzewoski ${ }^{2}$ and Agnieszka Śliwińska ${ }^{1, * \mathbb{D}}$ \\ 1 Department of Nucleic Acid Biochemistry, Medical University of Lodz, 251 Pomorska Str., \\ 92-213 Lodz, Poland; izabela.szymczak@umed.lodz.pl \\ 2 Central Teaching Hospital of the Medical University of Lodz, 251 Pomorska Str., 92-213 Lodz, Poland; \\ jozef.drzewoski@umed.lodz.pl \\ * Correspondence: agnieszka.sliwinska@umed.lodz.pl
}

Received: 9 August 2020; Accepted: 9 September 2020; Published: 11 September 2020

check for updates

\begin{abstract}
Numerous studies have shown that vitamin D deficiency is very common in modern societies and is perceived as an important risk factor in the development of insulin resistance and related diseases such as obesity and type 2 diabetes (T2DM). While it is generally accepted that vitamin $\mathrm{D}$ is a regulator of bone homeostasis, its ability to counteract insulin resistance is subject to debate. The goal of this communication is to review the molecular mechanism by which vitamin $\mathrm{D}$ reduces insulin resistance and related complications. The university library, PUBMED, and Google Scholar were searched to find relevant studies to be summarized in this review article. Insulin resistance is accompanied by chronic hyperglycaemia and inflammation. Recent studies have shown that vitamin D exhibits indirect antioxidative properties and participates in the maintenance of normal resting ROS level. Appealingly, vitamin D reduces inflammation and regulates $\mathrm{Ca}^{2+}$ level in many cell types. Therefore, the beneficial actions of vitamin D include diminished insulin resistance which is observed as an improvement of glucose and lipid metabolism in insulin-sensitive tissues.
\end{abstract}

Keywords: vitamin D deficiency; insulin resistance; adipose tissue; oxidative stress; sub-inflammation; epigenetic modification

\section{Introduction}

There is mounting evidence that vitamin D deficiency is now a worldwide health problem. In addition, an alarming number of diseases connected with vitamin $\mathrm{D}$ deficiency such as obesity and type 2 diabetes mellitus (T2DM) are observed. Both basic and clinical studies demonstrated that the majority of common characteristics of these diseases result from defects in insulin signaling, systemic inflammation, and pancreatic $\beta$-cells dysfunction [1-4]. It should be stressed that according to recent investigations one of the major causative factors in insulin resistance development is vitamin $\mathrm{D}$ deficiency. The results of some clinical studies have demonstrated that vitamin D supplementation improves major metabolic parameters associated with insulin resistance, including low-density lipoprotein (LDL), total cholesterol (TC), glycated hemoglobin (HbA1c), triglyceride (TAG), and homeostatic model assessment-insulin resistance (HOMA-IR). We have shown that three-month supplementation with vitamin D of the elderly with metabolic disorders markedly elevates HDL level, reduces HOMA-IR, and TG/HDL ratio. Moreover, we observed that $\mathrm{HbA1c}$ percentage decreased about $0.5 \%$ in T2DM patients after vitamin D supplementation [5]. In turn, Upreti et al. have revealed that six-month supplementation with vitamin D of T2DM patients leads to distinct reduction of $\mathrm{HbA1c}$ [6]. The results of study carried out by Mirrhosseini et al. have showed that vitamin D decreases $\mathrm{HbA} 1 \mathrm{c}$, fasting plasma glucose (FPG), and HOMA-IR contributing to better glycemic control [7]. Interestingly, Tabesh et al. have observed that co-supplementation of vitamin D with calcium decreases serum 
insulin level, HbA1c, HOMA-IR, LDL, and TC/HDL. Additionally, they also detected the significant elevation of quantitative insulin sensitivity check index (QUICKI) and HDL [8]. El Hajj et al. have found that vitamin D triggers to significantly diminish of HOMA-IR, FPG, TC, and LDL, but without any significant changes in $\mathrm{HbA1c}$ [9]. The results of studies conducted by Barzegardi et al. have presented pronounced decrease in serum levels of TG, LDL, and TC in diabetic nephropathy patients after supplementation with vitamin D [10]. Taken together, these observations support that vitamin D improves metabolic control of diabetes.

Vitamin D is involved in many cellular processes, e.g., the presence of its receptor and its metabolizing enzymes have been found in the cells of various tissues, including pancreatic $\beta$-cells, adipocytes, hepatocytes, and myocytes [11-14]. It also controls blood glucose concentration by regulating insulin secretion and insulin sensitivity [15]. Furthermore, it has been found to act in adipose tissue which is a major storage site of the vitamin [11]. It should be underlined that adipose tissue secretes numerous adipocytokines involved in inflammation, a typical feature of insulin resistance, obesity, and T2DM [11]. Numerous studies have revealed that vitamin D reduces the extent of inflammation and chronic hyperglycemia-generated oxidative stress [5,15]. Appealingly, vitamin D was demonstrated to modulate hepatic lipid and glucose metabolism [16]. Finally, it has also been shown that vitamin D counteracts diet-induced insulin resistance in skeletal muscle [17].

However, it should be also emphasized that the results of clinical studies have revealed no effect of vitamin D on insulin resistance and related disorders, including oxidative stress and inflammation. Lerchbaum et al. have shown that vitamin D supplementation did not change significantly metabolic parameters regarding insulin resistance and lipids in heathy men [18]. Forouhi et al. have found no effect of vitamin D on HbA1c, lipid and apolipoprotein levels, CRP, as well as anthropometric measures in subjects with increased risk of T2DM [19]. Similarly, Heshmat et al. have revealed no changes in $\mathrm{HbA1}$, anthropometric measures, and HOMA-IR in diabetic patients treated with vitamin D [20]. No differences in the FPG oral glucose tolerance test (OGTT) between prediabetes subjects supplemented with vitamin D in comparison to the placebo group have also been observed [21]. In addition, no significant changes between T2DM group and T2DM group supplemented with vitamin D have also been observed in the hs-CRP level, oxidative stress markers, LDL, HDL, and HbA1c [22]. In turn, Asemi et al. did not observe any significant changes in total plasma glutathione (GSH) and serum high sensitivity C-reactive protein (hs-CRP) level in pregnant women with gestational diabetes after supplementation with vitamin D [23].

Considering the above, the aim of this review is to provide a molecular insight into how vitamin $\mathrm{D}$ reduces insulin resistance and its consequences.

\section{Methods}

To summarize the current scientific literature devoted to the molecular mechanism involved in the reduction of insulin resistance and its consequences brought about by vitamin $\mathrm{D}$, the university library, PUBMED, and Google Scholar were searched to identify the relevant articles. The following keyword combinations were used: Vitamin D OR vitamin D action OR vitamin D receptor OR genomic action of vitamin D OR non-genomic action of vitamin D OR molecular mechanism of vitamin D OR vitamin D deficiency OR vitamin D insufficiency OR vitamin D supplementation AND insulin resistance OR intracellular calcium level OR insulin secretion OR insulin sensitivity OR insulin signaling OR pancreatic $\beta$-cells dysfunction OR skeletal muscle OR myocytes OR liver OR hepatocytes OR adipose tissue OR adipocytes OR adipogenesis OR adipocyte apoptosis OR adipocytokines OR adiponectin OR lipid metabolism OR glucose metabolism OR thermogenesis OR sub-inflammation OR epigenetic control OR oxidative stress OR reactive oxygen species OR immunomodulation OR immune cells. Subject to analysis were in vivo, in vitro, animal, as well as human studies, including clinical trials. 


\section{Vitamin D in Brief}

Vitamin $\mathrm{D}$, a cholesterol derivative, is one of the fat soluble vitamins. The term vitamin $\mathrm{D}$ refers to two forms: Ergocalciferol $\left(D_{2}\right)$ and cholecalciferol $\left(D_{3}\right)[24,25]$. Vitamin $D_{2}$ is formed by plants and mushrooms under ultraviolet $\mathrm{B}$ (UVB) radiation. Vitamin $\mathrm{D}_{3}$, on the other hand, is synthesized in the epidermis, where pro-vitamin $\mathrm{D}_{3}$-7-dehydrocholesterol, is transformed into pre-vitamin $\mathrm{D}_{3}$ under 290-315 nm UVB radiation. Subsequently, pre-vitamin $\mathrm{D}_{3}$ is converted into vitamin $\mathrm{D}_{3}$ in a heat-dependent process. It should be pointed out that about $20 \%$ of vitamin $\mathrm{D}$ comes from our diet, the remaining $80 \%$ being provided by our skin. Both vitamin $\mathrm{D}_{2}$ and $\mathrm{D}_{3}$ bind to the vitamin D-binding protein (VDBP) in the blood and are transported to the liver, where vitamin D 25-hydroxylase (CYP27A1 and CYP2R1) metabolizes it to 25-hydroxyvitamin D (25(OH)D) called calcidiol. The latter is a major circulating vitamin D form in the serum [26-28]. Calcidiol is further metabolized to 1,25-dihydroxyvitamin $\mathrm{D}\left(1,25(\mathrm{OH})_{2} \mathrm{D}_{3}\right.$; calcitriol) by $25(\mathrm{OH}) \mathrm{D} 1 \alpha$-hydroxylase (CYP27B1) in the proximal tubule of the kidney. Notably, CYP27B1 is expressed not only in the tubule of the kidney, but also in other cell types, including adipocytes, pancreatic $\beta$-cells, and macrophages. In turn, calcitriol is the most bioactive form of vitamin D that enters the circulation, binds to VDBP, and is then delivered to the target tissues, i.e., bone, kidney, and gut. It should be stressed that calcitriol has structural similarities to other steroid hormones, and for that reason it is classified as a hormone $[24,26,27,29-31]$. The level of calcidiol and calcitriol is regulated by 25(OH)D 24-hydroxylase (CYP24A1). The latter is a key vitamin D inactivating enzyme that performs hydroxylation of C-23 and C-24 of calcitriol and calcidiol. The inactivation of vitamin D occurs via two pathways, biliary excreted calcitroic acid is a product of the 24-hydroxylase pathway, whereas 1,25-26,23 lactone is formed in the 23-hydroxylase pathway [26,27].

In the cells of target tissues, calcitriol binds to the vitamin D receptor (VDR), which belongs to the nuclear receptor family and acts as a ligand-activated transcription factor, inducing both genomic and non-genomic response to vitamin $\mathrm{D}[32,33]$. In the genomic pathway, $1,25(\mathrm{OH})_{2} \mathrm{D}_{3}$ interacts with cytosolic VDR, which connects with retinoid $\mathrm{X}$ receptor (RXR). The formed complex translocates to the nucleus. Subsequently, the $1,25(\mathrm{OH})_{2} \mathrm{D}_{3}-\mathrm{VDR}-\mathrm{RXR}$ complex links with the vitamin D response element (VDRE) in the promoter region of vitamin D-responsive genes leading to recruitment of various enzymatic co-regulatory complexes engaged in facilitating the histones' epigenetic modification, chromatin remodeling, and the recruitment of local RNA polymerase II. In consequence, the expression of numerous vitamin D-responsive genes is regulated. Vitamin D responsive genes govern multiple processes such as differentiation, proliferation, angiogenesis, metabolism, and immunomodulation [34-36].

In turn, the activation of the non-genomic pathway by $1,25(\mathrm{OH})_{2} \mathrm{D}_{3}$ involves its binding with membrane VDR known as 1,25D-membrane-associated, a rapid response steroid-binding protein (1,25D-MARRS). The interplay between $1,25(\mathrm{OH})_{2} \mathrm{D}_{3}$ and 1,25D-MARRS switches on multiple cell signaling pathways via direct protein-protein interaction with numerous intracellular molecules [33,37]. The non-genomic pathway activated by vitamin $\mathrm{D}$ turns on numerous signaling molecules, including mitogen-activated protein kinases (MAPK)s, phosphatidylinositol-3 kinase (PI3K), $\mathrm{Ca}^{2+}$-calmodulin kinase II (CaMPKII), phospholipase C (PLC), protein kinase A (PKA), protein kinase C (PKC), and src. The plethora of kinases activated by vitamin $\mathrm{D}$ transduct the signal to the following transcription factors: RXR, SP1, and SP3, which subsequently bind to VDRE on the promoter of vitamin D-responsive genes. The activation of non-genomic pathway is a rapid response to $1,25(\mathrm{OH})_{2} \mathrm{D}_{3}$ based on numerous protein-protein interactions. Simultaneously, vitamin D is also engaged in the secretion of second messengers, such as $\mathrm{Ca}^{2+}$, cyclic AMP, 3-phosphoinositides, and fatty acids. However, it should be underlined that the type of signaling molecules activated by vitamin D depends on the cell type and the status of its maturation [38].

Vitamin D metabolism is regulated by the level of $1,25(\mathrm{OH})_{2} \mathrm{D}_{3}$ in a negative feedback mechanism $[39,40]$. Vitamin D inactivating enzyme CYP24A1 is a transcriptional target of $1,25(\mathrm{OH})_{2} \mathrm{D}_{3}-\mathrm{VDR}-\mathrm{RXR}$ complex. The promoter region of CYP24A1 includes two VDREs that are responsible for the induction of CYP24A1 
by $1,25(\mathrm{OH})_{2} \mathrm{D}_{3}$ [41]. Moreover, $1,25(\mathrm{OH})_{2} \mathrm{D}_{3}$ stimulates the expression of CYP24A1 by the recruitment of RNA II polymerase and histone $\mathrm{H} 4$ acetyltransferases to CYP24A1 gene [42]. Therefore, the level of both calcidiol and calcitriol is regulated by $1,25(\mathrm{OH})_{2} \mathrm{D}_{3}$-mediated CYP24A1 expression in the kidney. Furthermore, $1,25(\mathrm{OH})_{2} \mathrm{D}_{3}$ suppresses CYP27B1 transcription in the kidney by complex mechanisms engaging epigenetic modifications of CYP27B1 promoter region [43]. Additionally, studies revealed that vitamin D metabolism is regulated by fibroblast growth factor-23 (FGF-23) and parathyroid hormone (PTH). These biomolecules play a key role in the maintenance of $\mathrm{Ca}^{2+}$ and phosphate homeostasis [44-46]. FGF-23 is a hormone secreted by osteocytes and osteoblasts in response to both high serum level of $1,25(\mathrm{OH})_{2} \mathrm{D}_{3}$ and phosphate [45]. On the one hand, FGF-23 facilitates the secretion of phosphate by suppressing the expression of sodium-phosphate cotransporter 2 (NPT2) placed at the apical membranes of proximal renal tubules. On the other hand, FGF-23 decreases serum levels of $1,25(\mathrm{OH})_{2} \mathrm{D}_{3}$ by downregulation of CYP27B1 and upregulation of CYP24A1 in the kidney [47-49]. In turn, the parathyroid gland secretes PTH in a response to low level of $\mathrm{Ca}^{2+}$ in the serum [44]. PTH induces renal expression of CYP27B1 causing an increase of $1,25(\mathrm{OH})_{2} \mathrm{D}_{3}$ production $[50,51]$. It should be recognized that increased $1,25(\mathrm{OH})_{2} \mathrm{D}_{3}$ stimulates its own degradation via the activation of CYP24A1 expression, whereas PTH sustains the $1,25(\mathrm{OH})_{2} \mathrm{D}_{3}$ level by the kidney induction of CYP24A1 mRNA degradation [52,53]. Notably, a high $\mathrm{Ca}^{2+}$ level resulting in prolonged induction of $1,25(\mathrm{OH})_{2} \mathrm{D}_{3}$ negatively regulates PTH secretion by the parathyroid gland in a mechanism of negative feedback mechanism [54]. Figure 1 presents key information about vitamin D as described above.

\section{Vitamin D Level}

The serum level of calcidiol $(25(\mathrm{OH}) \mathrm{D})$ is thought to be a vitamin $\mathrm{D}$ status marker that reflects the actual amount of vitamin $\mathrm{D}$ in an organism $[55,56]$. A deficiency in vitamin $\mathrm{D}$ is considered primarily $25(\mathrm{OH}) \mathrm{D}$ concentration below $25-30 \mathrm{nmol} / \mathrm{L}(10-12 \mathrm{ng} / \mathrm{mL})$. There is no common agreement as to the optimal concentration of vitamin D, however it is generally accepted that the serum $25(\mathrm{OH}) \mathrm{D}$ level should not be lower than $50 \mathrm{nmol} / \mathrm{L}$ by the Scandinavian Nutrition Societies, The North American Institute of Medicine (IOM), the European Society for Clinical and Economic Aspects of Osteoporosis and Osteoarthritis, the D-A-CH nutrition societies, and the German Osteology governing body (DVO) $[57,58]$. On the other hand, the International Osteoporosis Foundation and the Endocrine Society considers $75 \mathrm{nmol} / \mathrm{L}$ ( $30 \mathrm{ng} / \mathrm{mL}$ ) of the calcidiol in the serum as an adequate vitamin D level.

It should be also underlined that the excess of vitamin $\mathrm{D}$ is toxic and manifests itself as a severe hypercalcemia [59]. Carmo et al. have demonstrated extensive vascular remodeling and elevated vascular calcification as a response to high doses of vitamin $\mathrm{D}$ in a murine model of obesity and insulin resistance [60]. It should be emphasized that vitamin D presents biphasic dose-responses (hormesis). In low doses it shows beneficial effect, but in high doses vitamin $\mathrm{D}$ is a toxic agent.

The percentage of people with vitamin D deficiency is continuously rising, especially in countries with low sun exposure. The main causes of vitamin D deficiency are alterations in vitamin $\mathrm{D}$ transformation and metabolism such as impaired absorption, increased catabolism, elevated urinary loss of $25(\mathrm{OH}) \mathrm{D}$, reduced synthesis, and impaired transport. Vitamin D deficiency may also be due to geographical factors, lifestyle, individual variables (i.e., skin pigmentation, skin grafts and aging), some disorders, and therapy with some drugs. Latitude, seasons, and the time of day are the geographical factors significantly affecting the volume of UVB photons that reach the earth according to the zenith angle of the sun. Latitude higher than $35^{\circ}$, the season from November to March, morning and late afternoon, as well as low position of the sun on the horizon are related to lower UVB index and decreased production of vitamin $\mathrm{D}$ in the skin [61]. The usage of sunscreens/sunoils, type of diet, obesity, breast-feeding, and indoor workplace also significantly decrease the level of vitamin D in the human body. Adipose tissue has been shown to sequestrate vitamin D, thus obesity is associated with its reduced availability [61]. It has also been noted that human milk contains a low level of vitamin D making infants susceptible to vitamin D deficiency during sole breast feeding [62,63]. 


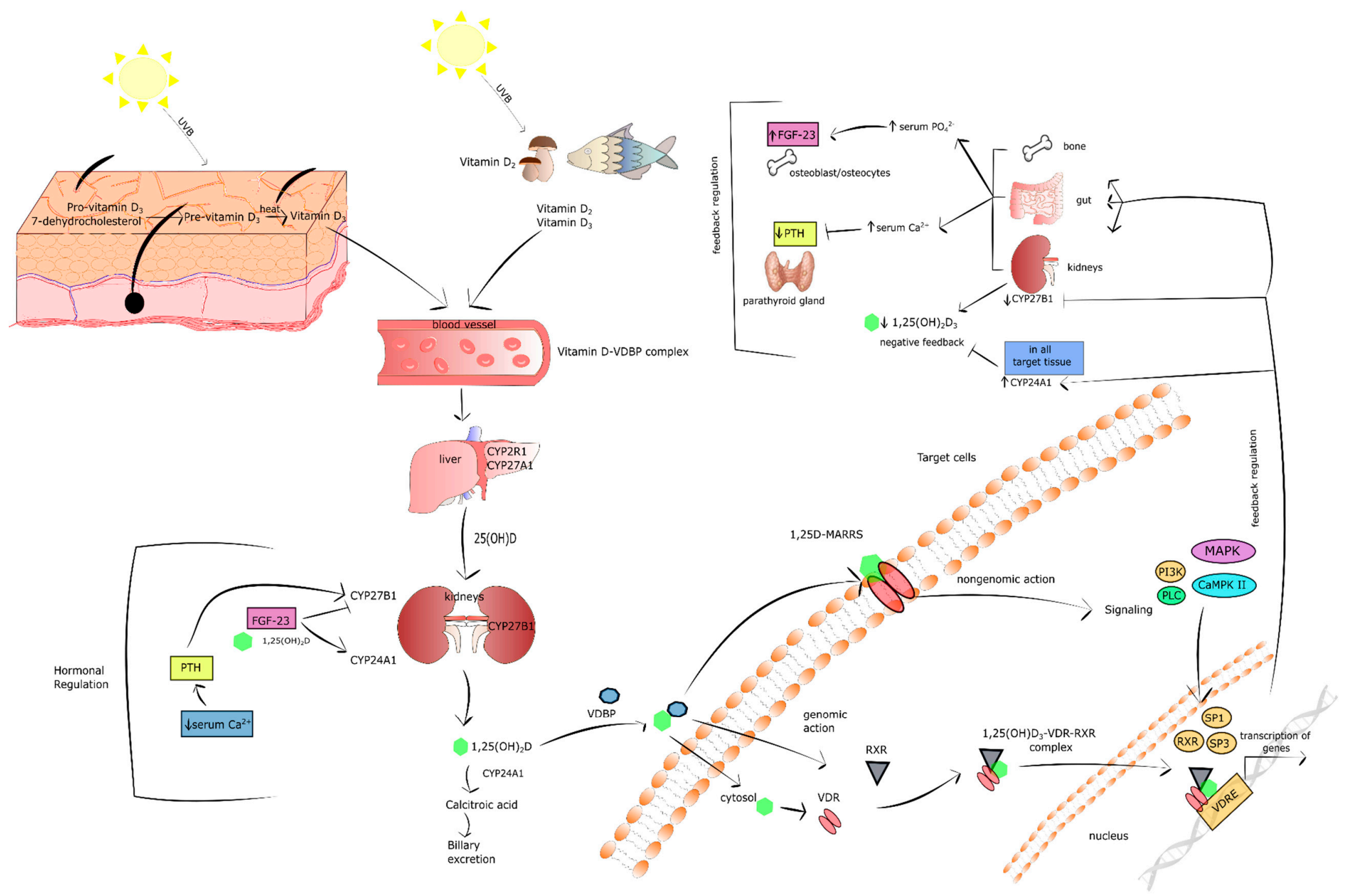

Figure 1. The overview of vitamin D. Stimulatory interactions are expressed by arrows and inhibition by T-bars. $\downarrow$ denotes decrease $\uparrow$ denotes increase. 
Individual features such as skin pigmentation, age and skin grafts also affect the synthesis of vitamin D. Skin pigmentation depends on the concentration of melanin, which is responsible for the absorption of UVB radiation. Thus, with dark-skinned people vitamin D production is five times lower as compared to white-skinned people (Caucasian). Interestingly, skin grafts due to burns and aging reduce the level of 7-dehydrocholesterol in the skin by about $75 \%$ in people aged 70 years and older [61].

Low vitamin D level is observed in people treated with cholesterol lowering medications, undergoing bypass surgery, suffering from celiac disease and chronic inflammatory bowel disease, and other conditions $[64,65]$. In subjects with chronic kidney disease, on the one hand, the synthesis of $1,25(\mathrm{OH})_{2} \mathrm{D}_{3}$ is inhibited, and-on the other-its metabolites are extracted from the body in higher amounts than in individuals with normal kidney function [61]. In turn, nephrotic syndrome is associated with increased loss of $25(\mathrm{OH}) \mathrm{D}$ with urine.

A significant catabolic effect of glucocorticoid, anticonvulsants, antirejection, AIDS treatment medications, and nucleoside/nucleotide reverse transcriptase inhibitors on vitamin D metabolism was also revealed [61]. In addition, rimfapicin and carbamazepine increase the level of PTH, which decreases the active form of vitamin $\mathrm{D}$ and in consequence increases its clearance [66-69].

Low concentration of vitamin D was reported in carriers of polymorphisms and mutations of VDBP and CYP27B1 genes. Numerous polymorphisms and mutations in genes associated with vitamin $\mathrm{D}$ transport and transformation were detected in all types of rickets [61].

\section{How does Insulin Resistance Develop?}

\subsection{The Physiology of Insulin Signaling}

One of the major regulators of energy homeostasis is insulin signaling [70]. Insulin receptor (IR), a member of the tyrosine kinase family receptors, is composed of extracellular $\alpha$ subunit and transmembrane $\beta$ subunit. IR activation occurs after insulin binding to $\alpha$ chain of IR that triggers structural changes in $\beta$ chain. The result of IR activation is the formation of the heterotetrameric structure followed by autophosphorylation of numerous tyrosine residues that are potential docking sites for the multiple components of various signaling pathways [71]. Thus, the recruitment and phosphorylation of different adaptor proteins, including substrate proteins, i.e., insulin-receptor substrate (IRS), is mediated by multiple phosphotyrosines [72]. Next, phosphorylated IRSs activate and translocate PI3K to the plasma membrane which phosphorylates the phosphatidylinositol 4,5-bisphosphate (PIP2) to phosphatidylinositol-3,4,5-trisphosphate (PIP3). The level of PIP3 is controlled by phosphatase and tensin homolog (PTEN) and SH2-containing inositol 5'-phosphatase-2 (SHIP2) that perform dephosphorylation of PIP3 [73]. Insulin-initiated elevated level of PIP3 activates serine-threonine kinase phosphoinositide-dependent protein kinase-1 (PDK1) causing both phosphorylation and activation of PKC $\zeta / \lambda$ and protein kinase B also called Akt. The two proteins increase glucose uptake by the translocation of GLUT to the cell membrane, including adipocytes' and muscle cells' membranes [74-76]. Moreover, Akt stimulates glycogenesis in the muscles and liver and lipogenesis in the adipocyte tissue, as well as the synthesis of protein, but represses proteolysis, lipolysis, gluconeogenesis, and glycogenolysis [77]. Interestingly, Liang et al. reported that sirtuin 1 (SIRT1) controlled the insulin-mediated phosphorylation of IR and IRS. SIRT1 is a NAD-dependent deacetylase that positively regulates insulin signaling via deacetylation of IRS-2, phosphorylation of IRS-1, repression of protein tyrosine phosphate non-receptor type 1 (Ptpn1) expression, and the activation of Akt in insulin-responsive cells [78]. It should also be pointed out that insulin, apart from its metabolic effects, is a growth factor engaged in cell growth, proliferation, and differentiation [79]. Its mitogenic activity occurs via the induction of MAPK cascade [77]. 


\subsection{The Mechanism of Insulin Resistance}

The typical signs of insulin resistance state are reduced uptake of glucose by skeletal muscle, liver, and adipose tissue, and diminished gluconeogenesis in the liver [70,79]. As a result, the blood glucose level pronouncedly increases and-if prolonged-it exerts a toxic effect on all cells, including those in insulin-sensitive tissues. For example, impaired insulin response in adipocytes contributes to increased release of free fatty acids (FFAs) into the circulation where they are uptaken by various organs, mainly by the liver. In turn, chronic hyperglycaemia leads to the overproduction of reactive oxygen species (ROS) and formation of oxidative stress. It is well documented that both glucotoxicity and lipotoxicity induce chronic inflammation and each of these pathologies accelerates the development of insulin resistance [80]. Several molecular pathways have been identified to play a key role in insulin resistance [70]. FFAs and related metabolites including ceramides, diacyloglycerol (DAG), acyl-CoA act on many protein kinases, including PKC $\zeta / \lambda$, PKC- $\theta$, nuclear factor- $\kappa B$ (NF- $\kappa B$ ), kinase- $\beta$ [I $\kappa B$ kinase- $\beta$ (IKK- $\beta$ )], Jun kinase (JNK), and trigger to IRS phosphorylation which, in turn, attenuates insulin signaling [80-84].

\subsubsection{Muscle}

It is well recognized that the systemic, increased availability of lipids, mainly elevated flux of fatty acids, enlarges the intramyocellular pool of long-chain fatty acyl-(CoA). This results in higher energy supply to mitochondrial oxidation and the synthesis of diacylglycerols (DAGs) for storage in the form of lipid droplets filled with TAG. The intramyocellular DAG level temporarily or permanently increases when the delivery and uptake of fatty acids exceed the ratio of mitochondrial long-chain fatty acyl-CoA oxidation and DAGs to TAGs incorporation. The latter phenomena provide elevated $\mathrm{C}_{18}$-containing DAGs in the cytosol and membrane activated novel protein kinase $C$ (nPKC) isoforms, i.e., PKC $\theta$. The translocation of PKC $\theta$ into the membrane enhances serine (1101 position) phosphorylation of IRS-1, which results in the inhibition of insulin-mediated tyrosine phosphorylation of IRS-1 and downstream kinases, including PI3K. The direct consequence of these events is the restraint of the recruitment of GLUT-4 to the cell membrane, impaired phosphorylation of glucose-6-phosphate (G-6-P), and reduced synthesis of glycogen [85]. The insulin resistance in skeletal muscle is shown in Figure 2.

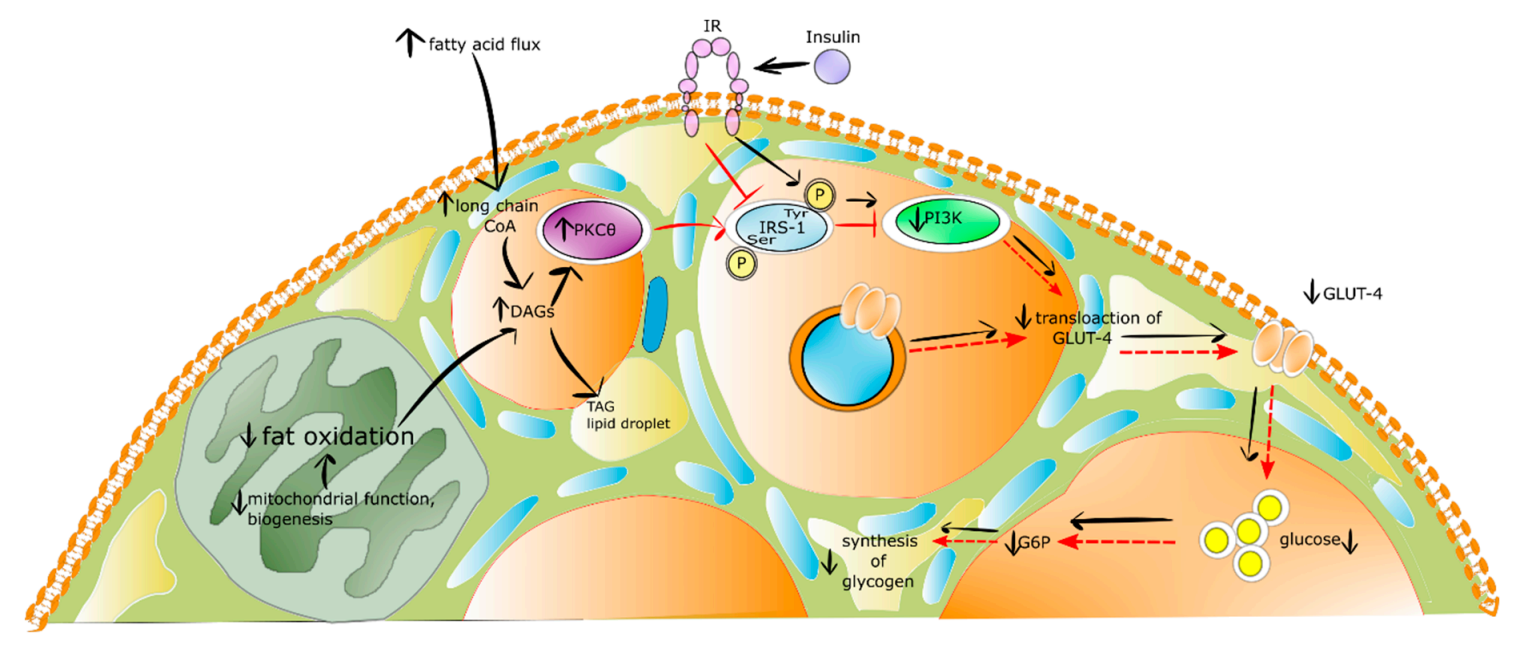

Figure 2. The insulin resistance mechanism in skeletal muscle. Stimulatory interactions are expressed by arrows and inhibition by T-bars, red color of arrow and T-bars denotes insulin resistance state, whereas black physiological state. $\downarrow$ denotes decrease $\uparrow$ denotes increase.

\subsubsection{Liver}

Prolonged and excessive intrahepatocellular influx of fatty acids leads to grow in the level of DAGs in the liver. In addition, the formation of DAGs in de novo lipogenesis, and re-estrification of fatty acids 
exceeds their incorporation into TAG in lipid droplets and mitochondrial oxidation. Subsequently, DAGs in the hepatocyte activate protein kinase $\mathrm{C} \varepsilon(\mathrm{PKC} \varepsilon)$ which phosphorylates tyrosines of IR. In turn, the phosphorylation of glycogen synthase kinase 3 (GSK3) and the phosphorylation of forkhead box subgroup $\mathrm{O}$ (FOXO) decrease. As a result of these events the activity of glycogen synthase, the storage of insulin-stimulated glycogen, and the transcription of FOXO-mediated gluconeogenic enzymes (i.e., G-6-P and phosphoenolpyruvate carboxykinase (PEP-CK)) are diminished. Finally, insulin-mediated suppression of hepatic gluconeogenesis occurs in insulin resistance-state [85]. The insulin resistance state in human liver is shown in Figure 3.

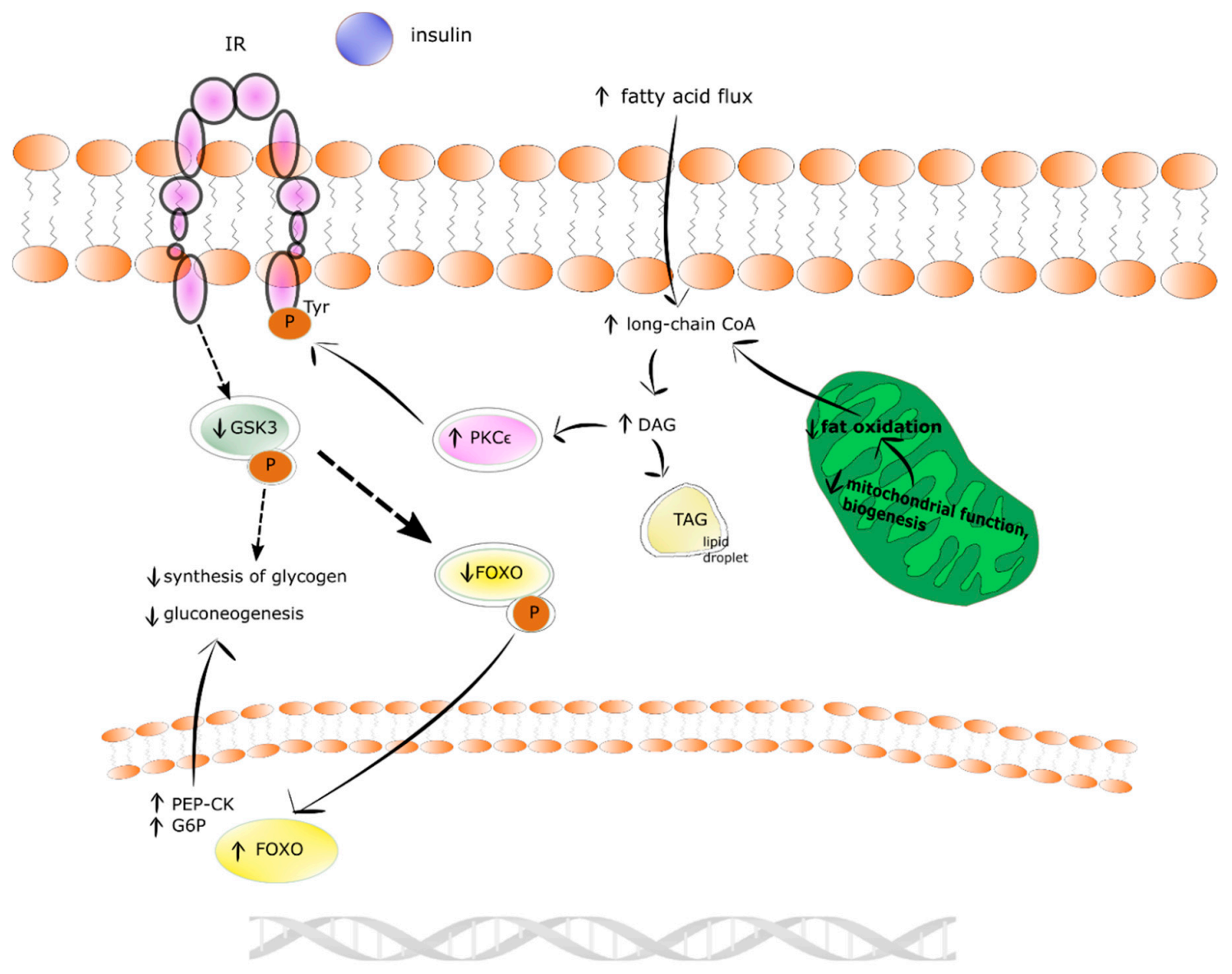

Figure 3. The insulin resistance mechanism in human liver. Physiological state is denoted by solid arrows and insulin resistant state by dotted arrows. $\downarrow$ denotes decrease $\uparrow$ denotes increase.

\subsubsection{Adipose Tissue}

Similarly, to hepatocytes and myocytes, the development of insulin resistance in adipocytes is related to impaired insulin signaling. The decreased IRS1 expression and increased IRS2, that are key substrate for PI3K, were found in insulin resistance state in adipocytes [86]. Moreover, insulin resistant adipocytes present decreased expression of GLUT4 [87] and alterations in the profile of secreted adipocytokines such as leptin, tumor necrosis factor $\alpha$ (TNF- $\alpha$ ), and adiponectin $[88,89]$.

Physiologically, the level of TNF- $\alpha$ is very low, but it increases in obesity states, leading to the acceleration of lipolysis and inhibition of lipogenesis. Interestingly, not only adipocytes, but also cells derived from stromovascular fraction such as macrophages, endothelial cells, fibroblasts, preadipocytes, smooth muscle cells, and leukocytes are an essential source of TNF- $\alpha$ in adipose tissue [90-94]. Appealingly, it was also proposed that the TNF- $\alpha$ role in insulin resistance development is associated with increased serine phosphorylation of IRS1 and decreased expression of GLUT4 [95,96]. 
Physiologically, insulin promotes TAG accumulation in adipocytes via the stimulation of preadipocytes' differentiation to adipocytes, elevation of glucose uptake and lipogenesis, as well as suppression of lipolysis $[88,97]$. The insulin action in adipocytes is mediated through two transcription factors: FOXO1 and SREBP1. SREBP1 regulates transcription of numerous adipocyte-specific genes required for fatty acid and lipid production [98-100]. In turn, FOXO1 that is activated by Akt, constitutes a trans-factor for the cis-element of peroxisome proliferation-activated receptor $\gamma$ (PPAR $\gamma$ ) promoters. PPAR $\gamma$, being a nuclear receptor, is a key regulator of adipogenic differentiation [101], and governs the expression of numerous adipocyte-specific genes [102]. Moreover, it was demonstrated that changes in the PPAR $\gamma$ activity affected the synthesis of adipocytokines, i.e., leptin, adiponectin, and were associated with insulin resistance. FOXO1 binds to the PPAR $\gamma$ promoter and suppresses its expression. Armoni et al. showed that the impaired ability of FOXO1 to translocate into the cell nucleus led to increased activity of PPAR $\gamma$ [103].

\section{How does Vitamin D Overcome Insulin Resistance and Related Disorders?}

\subsection{Vitamin D via the Regulation of $\mathrm{Ca}^{2+}$ Homeostasis Participates in Insulin Secretion by Pancreatic $\beta$-Cells}

The secretion of insulin by the pancreatic $\beta$-cells is a consequence of elevated blood glucose concentration. Glucose molecules flow into the pancreatic $\beta$-cells via the glucose transporter 2 (GLUT-2). Then, glucose breaks down in numerous metabolic pathways, which is ultimately accompanied by ATP production. Increased ATP suppresses the ATP-sensitive $\mathrm{K}^{+}$channel resulting in the depolarization of $\beta$-cell membrane followed by the activation of the L-type voltage-operated channels to produce the localized $\mathrm{Ca}^{2+}$ pulses crucial for the secretion of insulin [104].

Numerous studies showed that vitamin D deficiency is associated with impaired secretion of insulin by pancreatic $\beta$-cells [105-109]. Importantly, it was demonstrated that the supplementation with vitamin D restored proper secretion of the hormone $[105,107,110]$. However, it should be underlined that the findings concerning this issue are not unambiguous especially with regard to clinical trials [3,111-115].

One of the molecular mechanisms by which vitamin $\mathrm{D}$ participates in insulin secretion by pancreatic $\beta$-cells is the regulation of intracellular $\mathrm{Ca}^{2+}$ concentration. It was reported that $1,25(\mathrm{OH})_{2} \mathrm{D}_{3}$ reduced the expression of the L-type $\mathrm{Ca}^{2+}$ channels causing a decrease in intracellular $\mathrm{Ca}^{2+}$ concentration and thereby altering calcium signaling. In turn, rapid, non-genomic $1,25(\mathrm{OH})_{2} \mathrm{D}_{3}$ action was found to be responsible for the increase of cytoplasmic $\mathrm{Ca}^{2+}$ level that activates exocytosis of insulin in the pancreatic $\beta$-cells. Two vitamin D-mediated signaling pathways are involved in this process. The first includes PKA activation that phosphorylates various proteins engaged in the function of L-type voltage-dependent $\mathrm{Ca}^{2+}$ channels associated with insulin secretion. The second engages PLC synthesis and the activation of inositol triphosphate $\left(\mathrm{InsP}_{3}\right)$ triggering the secretion of $\mathrm{Ca}^{2+}$ from ER leading to DAG synthesis. Subsequently, DAG activates PKC that is responsible for the phosphorylation of the $\mathrm{K}_{\mathrm{ATP}}$ channels and L-type voltage-dependent $\mathrm{Ca}^{2+}$ channels. The latter trigger the depolarization of cytoplasmic membrane and opening of T-type $\mathrm{Ca}^{2+}$ and L-type channels that in consequence leads to the elevation of intracellular $\mathrm{Ca}^{2+}$ followed by insulin secretion [116]. PKC is also able to mobilize insulin secretory vesicles that together with increased $\mathrm{Ca}^{2+}$ concentration induce insulin secretion [117]. Furthermore, increased intracellular $\mathrm{Ca}^{2+}$ concentration stimulates insulin secretion via activation of CaMPKII. CaMPKII is a serine-threonine protein kinase occurring in secretory vesicles of insulin. Its primary function is the promotion of phosphorylation of numerous proteins involved in exocytosis, as well as mobilization of insulin vesicles [118]. Another study demonstrated that increased intracellular $\mathrm{Ca}^{2+}$ concentration is associated with the expression of insulin gene via cAMP-responsive element-binding protein (CREB). The activation of CREB occurs in response to numerous stimuli, including glucose growth factors (i.e., the insulin-like growth factor-1 (IGF-1)), incretin hormones (i.e., the glucagon-like peptide-1 (GLP-1), the gastric inhibitory polypeptide (GIP), the pituitary adenylate cyclase-activating polypeptide (PACAP)). All these stimuli lead to the 
phosphorylation of CREB at serine 133 residue. CREB is a crucial transcriptional element responsible for the efficient transcription of insulin gene, glucose sensing, exocytosis of insulin, and survival of pancreatic $\beta$-cells [119].

It is worth highlighting that the regulation of intracellular $\mathrm{Ca}^{2+}$ level by vitamin $\mathrm{D}$ is mediated by calbidin, a cytosolic $\mathrm{Ca}^{2+}$-binding protein involved in the stimulation of insulin secretion. Calbidin-D28k expression was found to be regulated by vitamin D $[113,120]$. It was also reported that $1,25(\mathrm{OH})_{2} \mathrm{D}_{3}$ increased the expression of calbindin D-9k, parvalbumin, the plasma membrane $\mathrm{Ca}^{2+}$-ATPase $1 \mathrm{~b}$, the sodium/calcium exchanger (NCX), and the $\mathrm{Ca}^{2+}$ pumps. All of these proteins are involved in the maintenance of low resting $\mathrm{Ca}^{2+}$ concentration in pancreatic $\beta$-cells [32,121-123].

Taken together, vitamin $\mathrm{D}$ is a potential modulator of depolarization-induced secretion of insulin via intracellular $\mathrm{Ca}^{2+}$ level regulation in pancreatic $\beta$-cells [120]. The effect of vitamin $\mathrm{D}$ on pancreatic $\beta$-cells is presented in Figure 4.

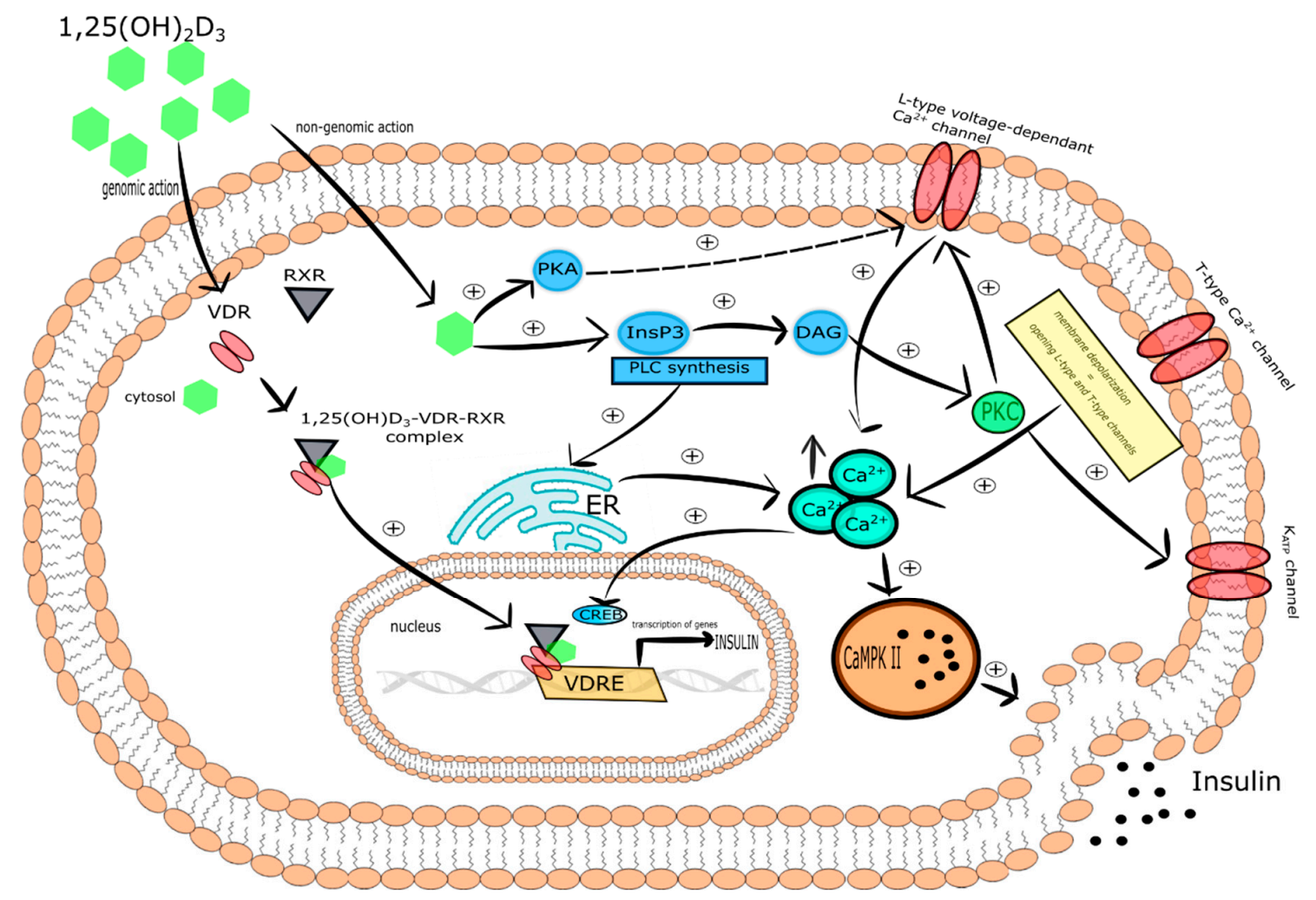

Figure 4. The effect of vitamin D on pancreatic $\beta$-cells. Stimulatory interactions are indicated by solid arrows and attenuation by dotted arrows. Enhancement is expressed by + . $\uparrow$ denotes increase.

\subsection{Vitamin D Controls $\mathrm{Ca}^{2+}$ Level in Myocytes and Adipocytes}

It is well known that $\mathrm{Ca}^{2+}$ are second messengers engaged in intracellular events induced by insulin in muscle and adipose tissue. That is why intracellular $\mathrm{Ca}^{2+}$ level changes have a substantial impact on multidirectional insulin actions. Numerous studies have demonstrated that the low level of $\mathrm{Ca}^{2+}$ in the cells of insulin targeted tissues is associated with reduced activity of glucose transporter followed by the development of peripheral insulin resistance [110].

Intracellular $\mathrm{Ca}^{2+}$ concentration in insulin-responsive tissues, including adipose tissue and skeletal muscle, is regulated by several mechanisms. The first mechanism involves the action of PTH that increases intracellular $\mathrm{Ca}^{2+}$ concentration in insulin-responsive tissues, including adipose tissue and skeletal muscle [124-126], as well as reducing insulin-induced transport of glucose [127,128]. Therefore, both growing intracellular $\mathrm{Ca}^{2+}$ concentration and the decreasing number of GLUT-1 and GLUT-4 on the cell membranes evoked by PTH promotes insulin resistance observed as reduced glucose 
uptake [128,129]. There is evidence that vitamin D deficiency is associated with increased PTH levels coexisting with insulin resistance $[130,131]$. Wright et al. have shown that vitamin D reduced insulin resistance in skeletal muscle as a result of elevation of intracellular $\mathrm{Ca}^{2+}$ concentration and strengthening of GLUT-4 translocation to the membrane of muscle cells and glucose uptake [132].

It has also been observed that vitamin D might decrease insulin resistance indirectly via the renin-angiotensin-aldosterone system (RAAS). It is well known that the RAAS system inhibits insulin action in peripheral tissues and regulates cellular $\mathrm{Ca}^{2+}$ concentration in skeletal muscle cells [132-134]. Interestingly, the increased expression of renin and secretion of angiotensin II, as well as $1,25(\mathrm{OH})_{2} \mathrm{D}_{3}$-mediated inhibition of renin biosynthesis have been observed in VDR-null mice [135-137]. Therefore, it was shown that vitamin D improved insulin sensitivity via inhibition of RAAS [138].

To conclude, vitamin D alleviates the insulin resistance state via regulation of $\mathrm{Ca}^{2+}$ level and RAAS action in insulin targeted tissue, including skeletal muscle and adipose tissue.

\subsection{Vitamin D-Mediated Improvement of Insulin Sensitivity Is Connected with Insulin Signaling}

Accumulating evidence uncovers multiple potential mechanisms by which vitamin D deficiency can contribute to insulin resistance. It is generally accepted that abnormalities in the insulin signaling pathway are responsible for the development of insulin resistance that is characterized by reduced reaction of target cells to circulating insulin.

It has been found that vitamin D mediated increase in insulin sensitivity occurs via binding of calcitriol to VDR [139], induction of IRs expression [140], and the activation of peroxisome proliferator-activated receptor delta (PPAR- $\delta$ ) [141]. The latter is a transcription factor engaged in the mobilization and metabolism of fatty acids in skeletal muscle and adipose tissue. What is more, activated PPAR- $\delta$ decreased FFAs-mediated insulin resistance in skeletal muscle. It was shown that $1,25(\mathrm{OH})_{2} \mathrm{D}_{3}$ activated PPAR- $\delta$ and improved insulin sensitivity. [141]. Manna et al. documented that vitamin D improved glucose metabolism as a result of upregulation of the SIRT1/IRS1/GLUT-4 signaling cascade and enhanced glucose uptake in high glucose-treated C2C12 myotubes [142].

The genomic pathway induced by $1,25(\mathrm{OH})_{2} \mathrm{D}_{3}$ in pancreatic $\beta$-cells, which express both VDR and CYP27B1, stimulates insulin synthesis and secretion since VDRE is present in the promoter region of the insulin gene $[113,116,143]$. Relevantly, studies performed on mice with the lack of functional VDR revealed that after glucose load, insulin synthesis and secretion were impaired [144]. Vitamin D-mediated improvement of insulin sensitivity is connected with insulin signaling. As a result of $1,25(\mathrm{OH})_{2} \mathrm{D}_{3}$-mediated transcriptional activation of IR gene, the number of IRs on the surface of insulin responsive cells increases. Thus, upregulation of the IR gene ensures proper insulin signaling $[140,145,146]$ and in this way calcitriol maintains insulin sensitivity $[140,145,147]$. It is suggested that vitamin D deficiency is involved in the onset of insulin resistance as a consequence of reduced expression of IR [2]. However, the results of vitamin D-mediated activation of IR expression in the liver are unambiguous. George et al. reported that vitamin D supplementation upregulated liver expression of IRs in streptozotocin-induced diabetic rats [148]. On the contrary, several studies failed to identify alterations in IR expression in the liver of mice fed with high-fat diet or low-fat diet [149], as well as in streptozotocin-induced diabetic rats after vitamin D supplementation [150].

To sum up, vitamin D alleviates insulin resistance via improvement of insulin signaling.

\subsection{Vitamin D Possesses Indirect Antioxidant Properties}

The pathogenic mechanism of insulin resistance is complex and has yet to be fully elucidated. Undoubtedly, the trigger factor in insulin resistance is adiposity, especially visceral, which is accompanied by chronic hyperglycemia, oxidative stress, and low grade chronic inflammation $[80,151]$. Additionally, a balance in the physiologic redox state is crucial for normal $\beta$-cells function, glucose homeostasis, and insulin sensitivity [152-154]. Oxidative stress is an imbalance between the production of reactive oxygen species (ROS) and the efficacy of antioxidant defense system. Endoplastic reticulum (ER) stress, hyperglycemia, dyslipidemia, lipid peroxides, and nitric oxide synthase, as well as advanced 
glycation end-products are involved in ROS overproduction in the insulin resistance diabetic state. It is well recognized that oxidative stress may activate several factors contributing to the development of insulin resistance $[155,156]$. Inoguchi et al. found that hyperglycemia and FFAs might activate ROS production via PKC-dependent stimulation of NADPH oxidase [157]. It was also observed that increased production of ROS is a key activator of insulin resistance $[158,159]$. Moreover, the association between the degree of insulin resistance and oxidative stress is suggested to induce cellular damage $[156,160,161]$. ROS have the ability to directly oxidize and damage cellular macromolecules, i.e., DNA, proteins, and lipids. Additionally, ROS may act as a signaling molecule that activates numerous cellular stress-sensitive pathways, i.e., NF-KB, JNK/SAPK, p38MAPK, and hexosamine involved in cellular damage and related pancreatic $\beta$-cells dysfunction, insulin resistance, and diabetes complication [162].

It is generally known that the hyperglycemic state is a causative factor responsible for the overproduction of ROS and reduced ATP formation that in turn exerts an effect on $\mathrm{Ca}^{2+}$ homeostasis leading to $\beta$-cell exhaustion and reduced resting insulin secretion. Furthermore, it is well recognized that the elevated formation of ROS increases the release of $\mathrm{Ca}^{2+}$ from ER via sensitization of the ryanodine receptors (RYRs) and inositol 1,4,5-trophosphate receptors ( $\mathrm{InsP}_{3} \mathrm{Rs}$ ). Reduced ATP level diminishes the capability of the $\mathrm{Ca}^{2+}$ pumps in ER and plasma membrane to press out $\mathrm{Ca}^{2+}$ from the cytoplasm outside of the cell. The effect may stimulate an increase of $\mathrm{Ca}^{2+}$ level in the pancreatic $\beta$-cells that triggers excessive insulin secretion leading to exhaustion of pancreatic $\beta$-cells [2]. Therefore, the elevated level of ROS strengthens $\mathrm{Ca}^{2+}$ signaling and may contribute to the onset of diabetes.

It was also proposed that oxidative stress coexisting with diabetes/chronic hyperglycemia is a result of increased FFAs levels that exert an effect on the mitochondria leading to increased ROS production (i.e., superoxide, hydrogen peroxide, hydroxyl radical ions) [163-166]. It was also suggested that vitamin D may regulate cellular bioenergetics in the mitochondria via VDR in the nucleus. This effect is related to the upregulation of numerous components involved in mitochondrial function, including mitochondrial respiration $[167,168]$. Additionally, VDR is capable of entering mitochondrion via permeability transition pores [169] and controls its functions, however this mechanism is still not fully understood [170]. It has also been found that vitamin D deficiency is connected with a decline in the mitochondrial respiration process. This effect is a consequence of the reduction of proteins and nuclear mRNA molecules engaged in this process $[167,168]$. Decreased respiration leads to a drop of mitochondrial bioenergetics related to alterations in oxidative phosphorylation, reduced ATP formation, and increased production of ROS [2]. Reduced expression of complex 1 of the electron transport chain contributes to the decrease of ATP production and ROS overproduction. In turn, increased ROS level reduces the activity of the insulin signaling pathways via lowering of GLUT-4 gene transcription, phosphorylation of IRS, disturbances in insulin signaling, and changes of mitochondrial activity [171-173]. These observations are supported by the results of a study showing that $1,25(\mathrm{OH})_{2} \mathrm{D}_{3} / \mathrm{VDR}$ signaling inhibits the process of differentiation of brown adipose cells and mitochondrial respiration [174]. Recently, Ricca et al. have demonstrated that VDR-mediated action of vitamin D may protect cells from overproduction of ROS and excessive respiration that leads to cell damage [175]. Vitamin D controls the balance of mitochondrial respiration via maintenance of mitochondrial respiratory chain activity [176] and the regulation of expression of uncoupling protein 1 (UCP1). UCP1 is localized on the inner membrane of mitochondria and is engaged in the regulation of thermogenesis [11]. The role of vitamin D in the maintenance of normal activity of mitochondria may explain at least partially the privileged relationship between diabetes and vitamin D deficiency.

Vitamin D has been shown to decrease ROS production in adipocytes [177] via the regulation of cellular antioxidants expression such as glucose-6-phosphate dehydrogenase (G6PD), glutathione peroxidase (Gpx), TR [178]. Interestingly, vitamin D together with Klotho and Nrf2 may control the expression of numerous antioxidants including catalase, Prx-2, Prx-3, SOD $\frac{1}{2}$, GSH, TR, G6PD, TRX, Trxrd-1, Gpx. It has been documented that vitamin D decreases the expression of NADPH oxidase which is responsible for the production of ROS [179], while increasing the expression of 
SOD $[178,180]$. Furthermore, vitamin D elevated the production of glutathione (GSH), a major redox buffer through the upregulation of glutamate cysteine ligase, glutathione reductase, and G6PD [181-183]. To conclude, it seems that antioxidant properties of vitamin $\mathrm{D}$ are indirect and related to its genomic and non-genomic action.

\subsection{Vitamin D Controls the Expression of Epigenetic Genes}

A link has been proposed between epigenetic mechanism and numerous diseases, including obesity and T2DM [184]. DNA methylation was found to be increased in obese individuals and declared to be one of the risk factors in the development of diabetes [185]. It was observed that vitamin D maintains the expression of DNA demethylases genes as a result of its genomic mechanism of action. Namely 1,25(OH $)_{2} \mathrm{D}_{3}$-VDR-RXR complex and its interaction with VDRE regulates the expression of vitamin D-dependent DNA demethylases (i.e., Jumonji domain-containing protein 1A and 3 (JMJD1A and JMJD3) and lysine-specific demethylase 1 and 2 (LSD1 and LSD2)). These enzymes perform demethylation of the promoter regions of numerous genes (i.e., ZEB1, ZEB2, SNAIL), and thereby prevent their hypermethylation $[2,186]$.

\subsection{Vitamin D Ensures Normal Function of Adipose Tissue}

Wamberg et al. showed that VDR is expressed in the subcutaneous adipose tissue (SAT) and visceral adipose tissue (VAT). The VDR expression is higher in the VAT of obese as compared to lean individuals. However, no difference was observed in the expression of VDR in SAT between obese and lean individuals [187]. The expression of VDR was also reported in primary adipocytes from obese patients [188], suggesting a possible role of vitamin D in the processes of adipose tissue development and metabolism. The effect of vitamin D on adipogenesis, adipocyte apoptosis, lipolysis, lipogenesis, thermogenesis, and inflammation has been recognized [188-193].

\subsubsection{Vitamin D Regulates Lipid Metabolism in Adipose Tissue}

It is widely known that adipocyte lipolysis is under hormonal regulation. Lipolytic hormones, including catecholamines, act via $\beta$-adrenergic receptors leading to increases in cAMP, which then activate cAMP-dependent PKA. Activated PKA, in turn, phosphorylates and activates enzymes of lipolysis [194]. Increased lipolysis coexisted with upregulated expression of fat oxidation markers such as CPT1 $\alpha$, PGC1 $\alpha$, PPAR $\alpha$, UCP1, SIRT-1, hormone-sensitive lipase (HSL), and lipoprotein lipase (LPL) [189]. It was demonstrated that $1,25(\mathrm{OH})_{2} \mathrm{D}_{3}$ inhibited adipocyte basal lipolysis in human adipocytes culture. Vitamin D increased the intracellular $\mathrm{Ca}^{2+}$ level [195] that caused a reduction of cAMP and a decrease in phosphorylation of HSL. In addition, Larrick et al. [196] and Chang et al. [189] have observed that calcitriol elevates the release of glycerol under basal and $\beta$-adrenergically stimulated murine 3T3-L1 adipocytes [189]. Summarizing, vitamin D exerts a suppressive effect on lipolysis.

It has been shown that the non-genomic mechanism of vitamin $\mathrm{D}$ action is involved in the regulation of adipocyte lipogenesis. Shi et al. reported that $1,25(\mathrm{OH})_{2} \mathrm{D}_{3}$ elevated the intracellular $\mathrm{Ca}^{2+}$ level and then the activity of fatty acid synthase (FSA). The observed effect was blocked by membrane antagonists and mimicked by membrane VDR agonists [195]. 1,25(OH $)_{2} \mathrm{D}_{3}$-dependent upregulation of FAS might be mediated by VDR [188,197]. The increased mRNA of LPL, protein expression of lipogenic enzyme fatty acid-binding protein (FABP), and elevated accumulation of TAG was observed in response to $1,25(\mathrm{OH})_{2} \mathrm{D}_{3}$ of differentiated subcutaneous human adipocytes of female and male donors with $25.6-50.9 \mathrm{~kg} / \mathrm{m}^{2}$ BMI range [190]. Moreover, the incubation of human adipocytes with $1,25(\mathrm{OH})_{2} \mathrm{D}_{3}$ evoked an increase in FAS protein level [195]. Interestingly, the increased expression of FAS in adipose tissue was not observed in Sprague-Dewley rats (16 days) after injection of $1,25(\mathrm{OH})_{2} \mathrm{D}_{3}$ [198]. Taken together, vitamin D may modulate the expression of lipogenic enzyme, however, further in vivo human studies are required to clarify these findings. 


\subsubsection{Vitamin D May Control Adipogenesis}

The participation of vitamin $\mathrm{D}$ in the process of adipogenesis has been explored. Along with the progress of adipocyte differentiation, VDR expression gradually decreases $[199,200]$. On the one hand, vitamin D was identified to promote adipogenesis in human and primary mouse preadipocytes [190]. On the other hand, however, the suppressive effect of vitamin $D$ on adipogenesis in mouse preadipocyte and 3T3-L1 cell line [199] and the inhibition of brown adipocyte differentiation have also been shown. Moreover, it is suggested that a high dosage of calcitriol may inhibit the early stages of adipogenesis in 3T3-L1 cells $[199,200]$. Calcitriol suppressive effect on adipogenesis is exerted via its action on numerous targets decreasing the expression of $\mathrm{C} / \mathrm{EBP} \alpha$ and PPAR $\gamma$, antagonizing the activity of PPAR $\gamma$ sequestrating RXR, as well as decreasing C/EBP $\beta$ mRNA and protein expression [200]. Blumberg et al. demonstrated that calcitriol stimulated the expression of eight twenty-one (ETO), a C/EBP $\beta$ corepressor. This molecule inhibits the action of C/EBP $\beta$ transcriptional activity that is required for adipogenesis [199].

Many signaling molecules, members of the WNT family, are released during preadipocyte differentiation. Physiologically, the WNT/ $\beta$-catenin pathway exhibits decreased expression during adipogenesis and is responsible for maintaining the preadipocytes in an undifferentiated state [201]. Vitamin D was found to inhibit differentiation of adipocytes via MAPK [202] and Wnt/ $\beta$-catenin signaling pathways $[11,203]$. It was also shown that calcitriol was involved in the regulation of the expression of the nuclear WNT10B and $\beta$-catenin, thereby suppressing PPAR $\gamma$ in a VDR-dependent manner leading to the inhibition of adipogenic differentiation in 3T3-L1 preadipocytes [199]. In addition, Cianferotti et al. revealed that $1,25(\mathrm{OH})_{2} \mathrm{D}_{3}$ diminished the level of secreted frizzled-related protein 2 (SFRP2) expression through VDR-dependent WNT signaling triggering to the suppression of mouse bone marrow stromal cells (BMSCs) differentiation [204]. Interestingly, calcitriol also demonstrated an inhibitory effect both on the mRNA expression and on phosphorylation of extracellular regulated kinase (ERK) resulting in the suppression of adipocyte differentiation [202]. Mesenchymal stem cells undergo differentiation towards adipocytes showing an accumulation of lipid droplets with coexisting increased expression of FABP4, PPAR $\gamma$, and FASN. Calcitriol was found to strengthen the expression of the above differentiation markers and accumulation of lipids [188]. Mahajan et al. observed that incubation of porcine mesenchymal stem cells (MSCs) with vitamin D activated both their differentiation and proliferation as a consequence of increased mRNA of adipocyte-binding protein 2 (AP2), PPAR $\gamma$, and LPL [205].

To conclude, vitamin D exerts an effect on the expression of genes engaged in adipogenesis. However, the results of studies focused on its influence on adipogenesis are inconsistent. Thus, further studies are required to further our understanding of the effect of vitamin D on adipogenesis.

\subsubsection{Vitamin D Is Engaged in Apoptosis of Adipocytes}

It is well documented that $\mathrm{Ca}^{2+}$ is a key player in apoptosis and due to the vitamin D effect on the regulation of intracellular $\mathrm{Ca}^{2+}$ level, it is suggested that the vitamin is involved in this process [206-208]. Sergeev et al. have proposed a mechanism of intracellular $\mathrm{Ca}^{2+}$ regulation and apoptosis by calcitriol in obesity. This process was initiated by the vitamin D-dependent stimulation of $\mathrm{Ca}^{2+}$ influx from the extracellular space and mobilization of $\mathrm{Ca}^{2+} \mathrm{ER}$ stores via the $\mathrm{Ins} \mathrm{P}_{3}$ receptor/Ca ${ }^{2+}$ release channel $\left(\mathrm{InsP}_{3} \mathrm{R}\right)$ and voltage-insensitive $\mathrm{Ca}^{2+}$ channels (VICC). Then, the activation of $\mu$-calpain by the sustained cytosolic $\mathrm{Ca}^{2+}$ signal was followed by the induction of $\mathrm{Ca}^{2+} /$ calpain-dependent caspase-12. These activated proteases seem to be sufficient for the execution of apoptosis [207]. By contrast, Sun et al. reported that calcitriol inhibited apoptosis and stimulated the expression of genes that promote the proliferation of human subcutaneous adipocytes [192]. They demonstrated that low doses of vitamin D suppressed, whereas high doses of calcitriol induced apoptosis of differentiated 3T3-L1 cells [209]. It was also suggested that low doses of vitamin $\mathrm{D}_{3}$ counteracted adipocyte apoptosis by elevating the ATP yield and mitochondrial potential, as well as suppressing UCP2 [210]. 
To summarize, decreased level of vitamin $\mathrm{D}$ in obesity and the action of $1,25(\mathrm{OH})_{2} \mathrm{D}_{3}$ to control mass of adipose tissue in vivo via regulation of adipocyte apoptosis may suggest a mechanistic role of vitamin D in adiposity [211]. However, further studies are required to better understand its role in adiposity and regulation of adipocyte apoptosis.

\subsubsection{Vitamin D Exerts an Effect on Thermogenesis}

Thermogenesis is a process of heat generation and a key mechanism responsible for the maintenance of stable body temperature. In the management of obesity, thermogenesis reduces stored fat in $\beta$-oxidation process leading to the production of heat and ATP. Human studies have shown that vitamin D supplementation decreased body weight and fat mass [212,213]. Similarly, vitamin D may increase apoptosis of adipose cells in mice with diet-induced obesity which results in loss of weight [214]. Moreover, elevated fat oxidation and thermogenesis after vitamin D-rich breakfast intake show a direct relation between vitamin D and metabolism [215]. Brown adipose tissue expresses UCP1 that enhances thermogenesis. It has been shown that expression of UCP2 is inhibited by VDR after $1,25(\mathrm{OH})_{2} \mathrm{D}_{3}$ treatment of human adipocytes [193]. The increased expression of UCP2 driven by calcitriol leads to accelerated thermogenesis in mice with a high calcium diet. By contrast, Wong et al. have shown that VDR null mice have decreased storage of body fat, reduced level of cholesterol, and TAG under normal calcium concentration as compared to wild type mice suggesting that vitamin D did not mediate the loss of body fat. Additionally, white adipose tissue has shown a higher ratio of $\beta$-oxidation and upregulation of UCP1, UCP2, UCP3 in VDR-null mice as compared to wild type mice [216].

Taken together, the result of studies aimed to establish the effect of vitamin D on the regulation of thermogenesis and storage of body fat are inconclusive. Thus, further studies are required to better understand its role in these processes.

\subsection{Vitamin D Decreases Low-Grade Chronic Inflammation Coexisting with Insulin Resistance}

5.7.1. Anti-Inflammatory Properties of Vitamin D Are Driven by the Reduction of Adipocytokine Production

It is well recognized that hypertrophic enlargement of adipose tissue is related to insufficient blood flow leading to hypoxia, macrophages infiltration, and inflammation, a typical feature of obesity $[217,218]$. The hypertrophied adipocytes overproduce pro-inflammatory cytokines such as TNF- $\alpha$, IL-8, MCP1, IL-6, and resistin, as well as secreting less adiponectin [219-221]. In consequence, the dysregulation of many signaling pathways in hypertrophic adipose tissue causes insulin resistance [11,71-74,77,222-224]. Many acute phase proteins and pro-inflammatory cytokines are responsible for undesired crosstalk with biomolecules of insulin signaling [225]. For example, TNF- $\alpha$ and other pro-inflammatory cytokines influence the peripheral insulin sensitivity via the inhibition of insulin-dependent tyrosine phosphorylation of IRS-1. This effect then leads to improper activation of downstream insulin signaling molecules, including PI3-kinase and translocation of GLUT-4 to the cell surface $[226,227]$. It is known that angiotensin II and cytokines, i.e., monocyte chemotactic protein 1 (MCP1), TNF- $\alpha$, IL-6, as well as other inflammatory factors engaged in inflammation may activate numerous intracellular protein kinases (i.e., JNK, S6 K, IKK, PKC) that phosphorylate IRS1 and IRS2 followed by attenuation of insulin signaling [133,219,226,228-232]. Therefore, low-grade chronic inflammation and increased adipose tissue infiltration of immune cells are strictly associated with both local and whole-body adipose tissue insulin resistance [229,233].

The action of vitamin D in adipose tissue is not only connected with the presence of VDR and enzymes involved in its metabolism, but also with its anti-inflammatory properties [11,234,235]. In vitro studies have shown that $1,25(\mathrm{OH})_{2} \mathrm{D}_{3}$ suppresses chronic inflammation in both mouse 3T3-LI cell line and human adipocytes as a result of diminished secretion of pro-inflammatory cytokines [233,236,237]. $1,25(\mathrm{OH})_{2} \mathrm{D}_{3}$ was also reported to decrease the activity of pro-inflammatory cytokines (i.e., MCP-1, 
IL-6, TNF- $\alpha$, and IL-1 $\beta$ ) in macrophages [229,233]. In turn, Chang et al. have shown increased protein and mRNA of TNF- $\alpha$, IL-6, and macrophage infiltration in adipose tissue of Sprague-Dawley male mice fed with a high-fat low vitamin D content diet as compared to high-fat diet supplemented with 1000 IU of vitamin D per kg [238].

Another anti-inflammatory mechanism of vitamin $\mathrm{D}$ action found in murine adipocytes and human preadipocytes involves the inhibition of NF- $\mathrm{kB} / \mathrm{MAPK}$ pathway [239-243]. NF- $\mathrm{kB}$ is known to be an important component of inflammatory pathways in adipose tissue. Its activation and translocation of p65 subunit to the nucleus is a result of IKB $\alpha$ degradation [244]. TNF- $\alpha$ - or LPS- stimulated receptors (i.e., IL-6R, TLR) activate NF- $\mathrm{KB}$ or p38MAPK-mediated transcription of pro-inflammatory genes (i.e., IL-6, IL-1 $\beta$, and TNF- $\alpha$ ). Cannel et al. showed that calcitriol inhibited I $\kappa$ B $\alpha$ phosphorylation and then translocation of NF-kB or p38MAPK into the nucleus [245]. Mutt et al. revealed that calcitriol suppressed the release of LPS-stimulated IL-6 in mature human adipocytes and differentiated MSC [240]. Moreover, it was demonstrated that $1,25(\mathrm{OH})_{2} \mathrm{D}_{3}$ reduced IL- $1 \beta$-activated expression of pro-inflammatory genes including MCP-1, IL-6, and IL-8. However, the findings from in vitro studies are not in line with in vivo outcomes. On the one hand, Wamberg et al. reported that oral supplementation with vitamin D (700 IU per day) for 26 weeks did not reduce adipose tissue expression or circulating levels of IL-6, IL-8, and MCP-1 in obese patients [246]. On the other hand, in a mice model of obesity induced by a high-fat diet supplementation with calcitriol reduced IL-6 level in adipose tissue was observed [236].

It should be underlined that numerous cytokines activate kinases from both the Jun N-terminal kinase 1 (JNK1) and IKK- $\beta / \mathrm{NF}-\mathrm{KB}$ pathways. In turn, these activated kinases phosphorylate IRS-1 leading to the impairment of insulin signaling [61,74]. Therefore, excessive secretion of pro-inflammatory cytokines triggers dysregulation of glucose and lipid metabolism [247]. Several studies demonstrated that vitamin D decreases monocyte chemotaxis, secretion of cytokines and chemokines playing an important role in reducing the extent of inflammation $[70,76,80,81]$.

To conclude, numerous data indicate that vitamin $\mathrm{D}$ inhibits the release of pro-inflammatory cytokines $[229,231,248]$, i.e., TNF- $\alpha$, IL-6, and C-reactive protein $[249,250]$. The bioactive form of vitamin D strongly suppresses the activation of NF- $\mathrm{KB}$ and MAPK signaling pathways preventing transcription of pro-inflammatory genes. Thus, calcitriol significantly reduces the inflammation in adipose tissue.

\subsubsection{Vitamin D Regulates the Production of Adipokines}

Recent data found that vitamin D was engaged in the regulation of adipokines release such as adiponectin and leptin [251-253]. Leptin released by adipose tissue acts on the hypothalamus that suppresses appetite and increases energy expenditure [254]. This hormone regulates the metabolism of lipids via the activation of lipolysis and suppression of lipogenesis [241,242]. Interestingly, the synthesis of leptin is induced by insulin, glucocorticosteroids, TNF- $\alpha$, and estrogens, but it is suppressed by FFAs and growth hormones [255]. A positive correlation between leptin level and body fat mass is well documented [256]. It was revealed that vitamin D mediated, not only adipokines release, but also energetic homeostasis via the regulation of leptin formation. Another study showed that vitamin D suppressed the secretion of leptin by adipose tissue [257]. Additionally, CYP27B1 knockout mice were hypoleptinemic and consumed more food as compared to their wild type counterparts. In turn, VDR knockout (VDRKO) mice exhibited lean phenotype, hypoleptinemia, and hyperphagia related to reduced serum level of leptin [258]. The adipose tissue mass determines the level of leptin in the serum. It was not fully understood whether hypoleptinemia is a result of body fat content or is a direct result of action of the vitamin D/VDR system on leptin expression in VDRKO mice. $1,25(\mathrm{OH})_{2} \mathrm{D}_{3}$ directly initiates both the expression and secretion of leptin in wild-type mouse adipose tissue cultures. However, this effect was not observed in VDR-null mice adipose tissue cultures. It has also been found that $1,25(\mathrm{OH})_{2} \mathrm{D}_{3}$ decreases the expression of leptin by at least $84 \%$ in mouse 3T3-L1 adipocytes [259]. Notably, leptin was found to suppress the renal transformation of vitamin $\mathrm{D}_{3}$ to its active metabolite 
indirectly via the stimulation of osteoblast and/or osteocyte production of FGF-23 [260]. FGF-23 suppresses the synthesis of calcitriol via inhibition of renal CYP27B1 [261].

Adiponectin is an anti-inflammatory and insulin-sensitizing hormone $[262,263]$ that is considered as a biomarker of insulin resistance [255]. Its biological action depends on its serum level, the type of isoforms, and subtype of tissue specific receptor. The negative correlation between circulating adiponectin level and body mass index (BMI) is widely known. The downregulation of adiponectin, especially the HMW isoform has been found in obese children characterized by vitamin D deficiency $[11,253]$. Contrariwise, the elevated adiponectin level was identified in patients with T2DM supplemented with vitamin D-fortified food [264]. Moreover, calcitriol treatment increases adiponectin expression and disulfide bond-A oxidoreductase-like protein (DsbA-L). DsbA-L is a key protein involved in the multimerization of adiponectin [253]. On the one hand, no effect of calcitriol on the expression of adiponectin in human adipocyte culture was observed [265]. On the other hand, calcitriol was demonstrated not only to inhibit TNF- $\alpha$-induced release of MCP-1, but also to suppress the release of adiponectin from differentiated adipocytes of subcutaneous VAT [266]. The effect of vitamin D on adipocyte function is summarized in Figure 5.

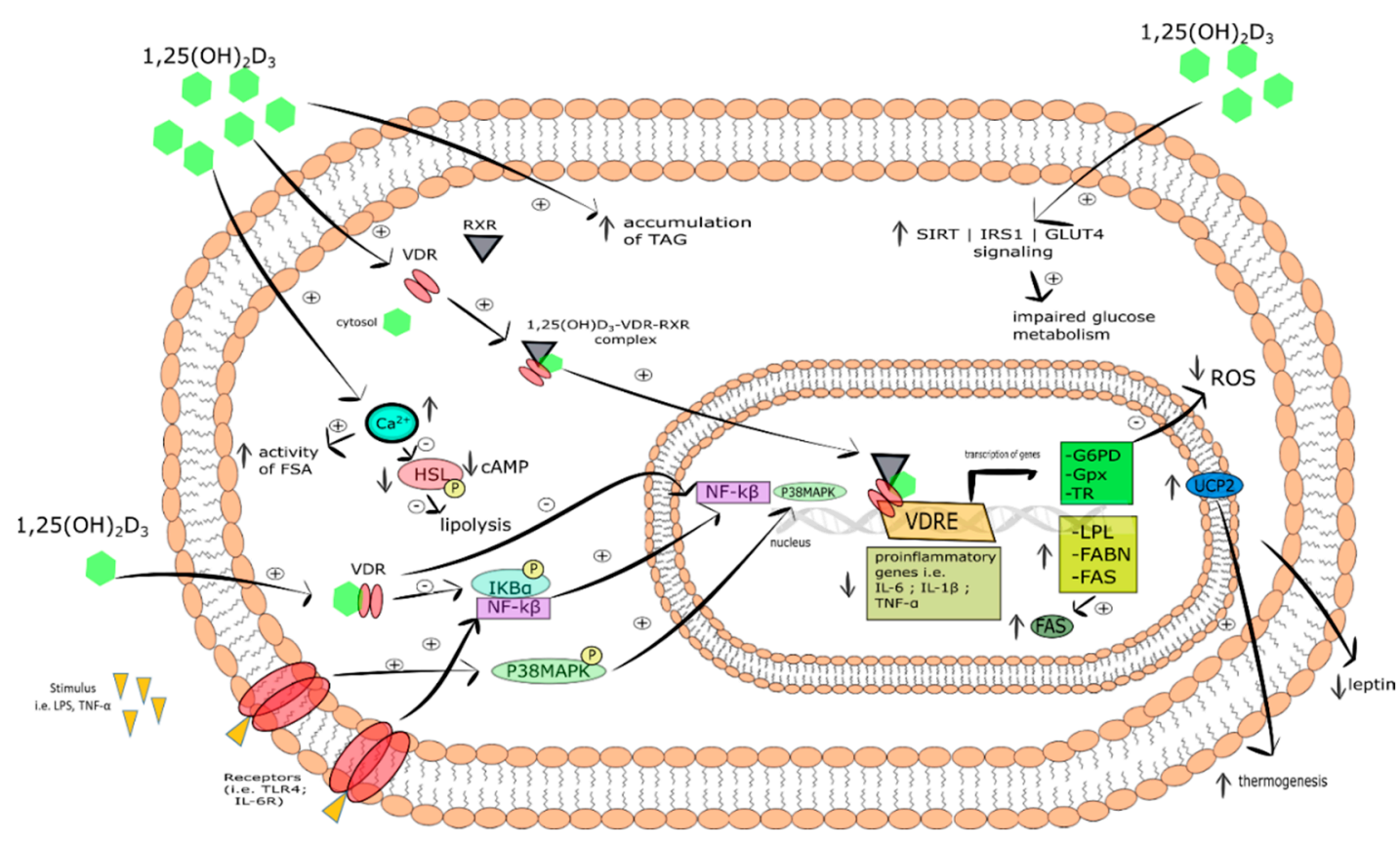

Figure 5. The effect of vitamin D on adipocyte function. Stimulatory interactions are indicated by + and inhibition by -; $\downarrow$ denotes decrease $\uparrow$ denotes increase.

\subsection{Vitamin D Regulates Lipid and Glucose Metabolism in Muscle Tissue and Liver}

\subsubsection{Skeletal Muscle}

Gilsanz et al. demonstrated that increased infiltration of fat in skeletal muscle tissue associated with insulin resistance and related vitamin $\mathrm{D}$ deficiency takes place independently of body mass increase [267]. Another study showed that the exposure of L6 and C2C12 myotubes to $1,25(\mathrm{OH})_{2} \mathrm{D}_{3}$ evoked increased expression of VDR, insulin receptor, and GLUT-4 [268,269]. What is more, it was demonstrated that the incubation of $\mathrm{C} 2 \mathrm{C} 12$ myotubes with $1,25(\mathrm{OH})_{2} \mathrm{D}_{3}$ ameliorated lipid-induced insulin resistance by increased tyrosine phosphorylation of IRS-1 and serine phosphorylation of AKT $[270,271]$. Calcitriol was also able to increase mRNA of adipose triglyceride lipase (ATGL) and perilipin 2 (PLIN 2) in C2C12 myotubes, thereby revealing its engagement in intramuscular lipid catabolism and lipolysis [272]. 
Another mechanism of calcitriol action on skeletal muscle includes mitochondria. Ryan et al. found that the incubation of human primary muscle cells from healthy lean donors with calcitriol improved mitochondrial morphology and decreased mRNA of carnitine palmitoyltransferase 1 A (CPT1A) and pyruvate dehydrogenase kinase 4 (PDK4) which participate in muscle lipid and glucose metabolism [273].

Taken together, vitamin D may exert an effect on muscle insulin sensitivity by the improvement of glucose and lipid metabolism, mitochondrial function, and lipid turnover. However, further studies are needed to determine the importance of vitamin $\mathrm{D}$ in insulin sensitivity in muscle tissue. The mechanism of vitamin D action in myocyte is presented in Figure 6.

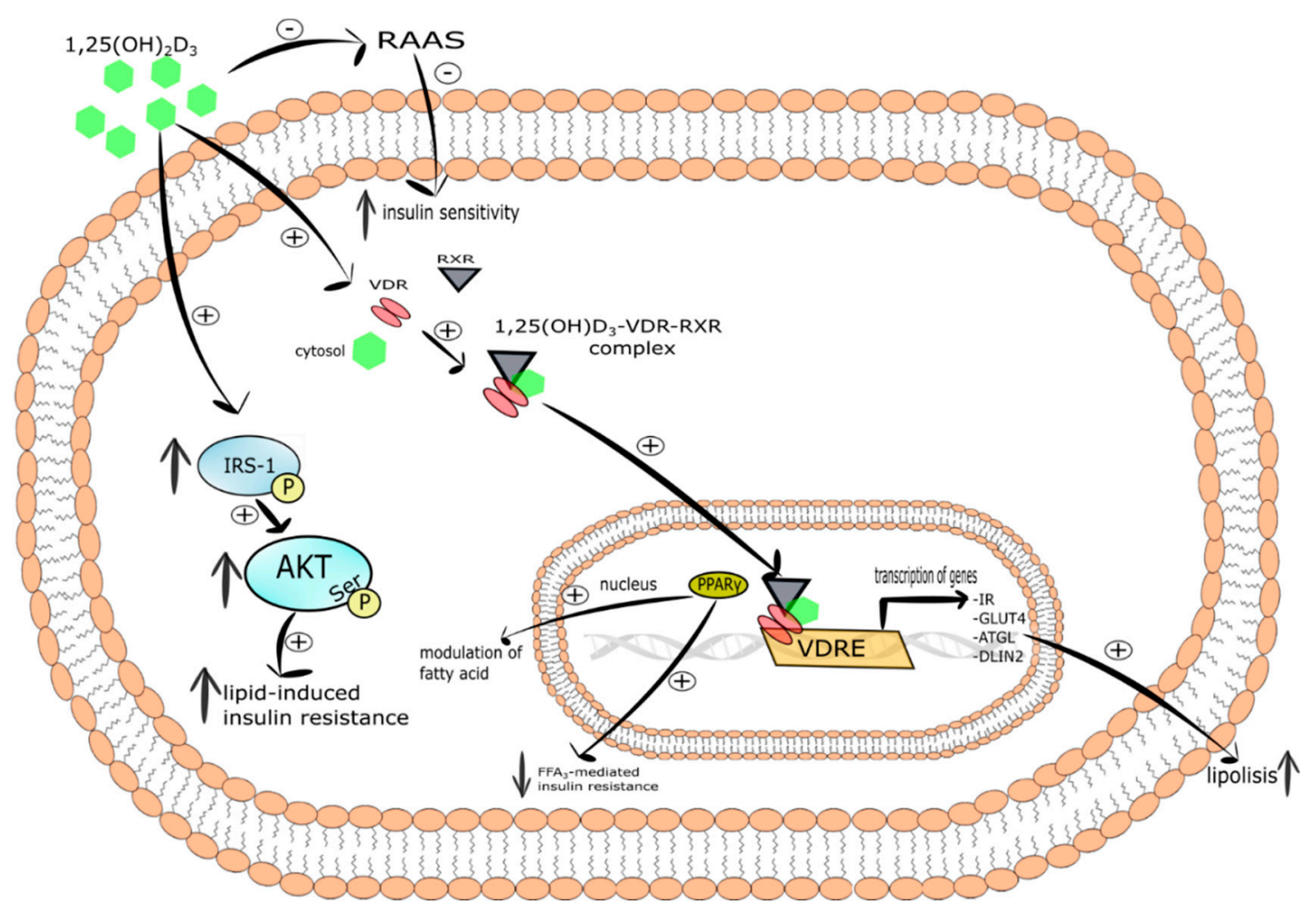

Figure 6. The mechanism of vitamin D action in myocyte. Stimulatory interactions are indicated by + and inhibition by $-; \downarrow$ denotes decrease $\uparrow$ denotes increase.

\subsubsection{Liver}

It is well recognized that obesity is associated with excessive deposition of fat in the liver being a result of hepatic insulin resistance and inflammation [274]. Kong et al. have shown that intrahepatic injection of calcitriol in a dose of $5 \mathrm{ng} / \mathrm{g}$ body weight, twice per week for four weeks to vitamin D deficient mice fed with a high fat diet evoked the downexpression of pro-inflammatory markers and genes connected with hepatic lipogenesis, as well as the upregulation of bile acid transport [275]. Similarly, intraperitoneal injection of $1,25(\mathrm{OH})_{2} \mathrm{D}_{3}$ in a dose of $2.5 \mathrm{ng} / \mathrm{g}$ body weight, three times per week for four weeks decreased liver fat accumulation in mice [276].

Vitamin D was reported to affect hepatic lipogenesis and gluconeogenesis. This action is mediated via numerous vitamin D-regulated pathways, i.e., Akt/Notch signaling and/or AMP-activated protein kinase (AMPK)-calmodulin. The enzymatic property of AMPK is induced by phosphorylation through either serine/threonine kinase 11 pathways or the calcium/calmodulin protein kinase beta $(\mathrm{CaMKK} \beta)$. Hepatic AMPK activation leads to the promotion of lipid oxidation and glycolysis, as well as attenuation of lipogenesis and gluconeogenesis [277]. Moreover, the induction of AMPK suppresses Foxo1 activity [278] causing the decrease in ER stress and attenuation of insulin resistance and steatosis $[279,280]$. It has been demonstrated that high doses of calcitriol ameliorates the abnormal 
hepatic glucose and lipid metabolism in insulin resistance models without toxicity symptoms. Lin et al. have shown that the elevated level of cytosolic $1,25(\mathrm{OH})_{2} \mathrm{D}_{3}$ in HepG2 cells evoked the induction of $\mathrm{Ca}^{2+} / \mathrm{CaMKK} \beta / \mathrm{AMPK}$ pathway. Additionally, calcitriol was found to ameliorate hepatic steatosis by the upregulation of autophagy-related mRNA genes such as ATG16L1 showing that vitamin D may stimulate lipophagy by the autophagy-lysosomal pathway [276]. Nelson et al. have shown an inverse correlation between the serum level of $25(\mathrm{OH}) \mathrm{D}_{3}$ and hepatocyte damage in obese women and men with steatohepatitis [281]. However, no correlation has been observed between the serum vitamin D level and fat accumulation in the liver or insulin sensitivity in obese women and men with steatohepatitis [282].

To summarize, vitamin D may ameliorate hepatic lipid and glucose abnormalities in vitro and in vivo via activation of $\mathrm{Ca}^{2+} / \mathrm{CaMKK} \beta / \mathrm{AMPK}$ signaling. The action of vitamin $\mathrm{D}$ in hepatocyte is shown in Figure 7.

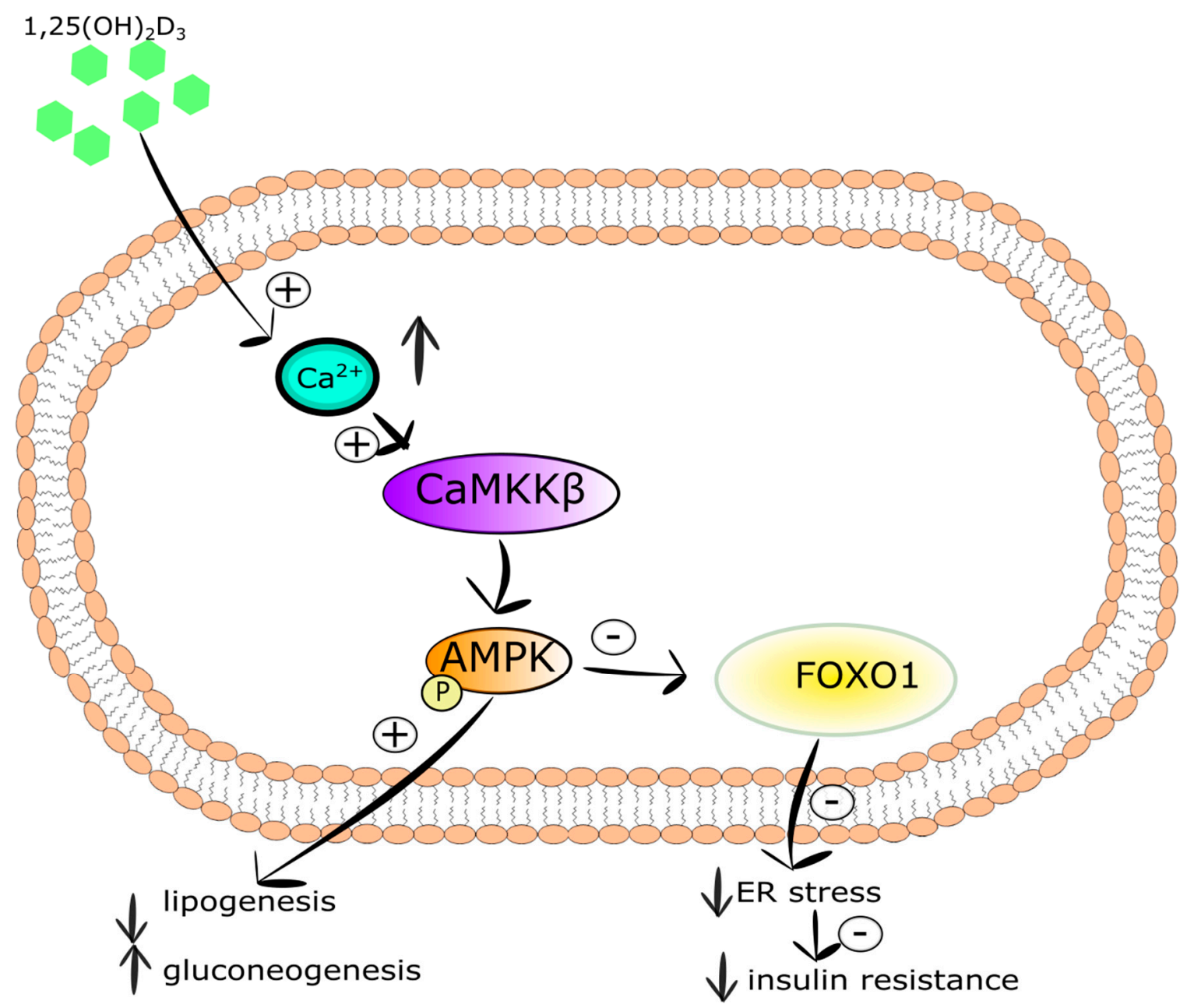

Figure 7. The action of vitamin $\mathrm{D}$ in hepatocyte. Stimulatory interactions are indicated by + and inhibition by -; $\downarrow$ denotes decrease $\uparrow$ denotes increase.

\subsection{Immunomodulatory Function of Vitamin D}

The immunomodulatory function of calcitriol is widely known [29,283]. Vitamin D not only decreases adipose tissue inflammation by influencing leukocyte infiltration and maturation of adipocytes [284,285], but also acts on both the innate and adaptive immune system [245]. Vitamin $\mathrm{D}$ reduces the secretion of pro-inflammatory cytokines such as IFN- $\gamma$, TNF- $\alpha$, IL-12 and increases production of anti-inflammatory cytokines (IL-10). Additionally, it was recognized that dendritic cells 
acquire an immunoregulatory function and tolerogenic properties as a result of vitamin D action [286]. It is also known that vitamin $\mathrm{D}$ reduces the expression and secretion of pro-inflammatory cytokines such as TNF- $\alpha$, IL-1 $\beta$, IL-8, and IL-6 in monocytes $[287,288]$. Moreover, vitamin D is involved in the change from more inflammatory response of T-helper 1 (Th1)/Th17 to less inflammatory Th2/Treg profile in lymphocytes [289]. Interestingly, the T lymphocyte activity is modulated in obesity [290]. Regulatory T cells (Treg) are subtypes of T lymphocytes. Treg are significantly decreased in VAT in obese mice [291]. Recent evidence has shown two crucial immunological mechanisms associated with insulin resistance namely, obesity-dependent and obesity-independent. Obesity-dependent insulin resistance is characterized by macrophage-driven inflammation [292]. In turn, obesity-independent mechanism involving age-related insulin resistance is controlled via adipose-resident regulatory T cell (aTreg) [293]. Calcitriol was demonstrated to reduce inflammation through strengthening the suppressive Tregs activity [291]. However, the action of vitamin D on aTreg is still not fully understood [294].

Considering the presence of numerous immune cells in adipose tissue and vitamin D actions, it alleviates the inflammation driven by insulin resistance [295].

\section{Conclusions}

Apart from mineral and bone metabolism regulation, vitamin $\mathrm{D}$ is also involved in a great number of cellular processes responsible for the homeostasis of glucose and lipid metabolism via insulin signaling pathway. Accumulating evidence supports that vitamin D deficiency is associated with the pathogenesis of insulin resistance. Disturbances in insulin signaling and inflammation are closely related, and vitamin D was found to reduce both of these disorders. Current evidence suggests that these benefits are the effect of vitamin $\mathrm{D}$ on $\mathrm{Ca}^{2+}$ and $\mathrm{ROS}$ homeostasis, as well as regulation of the expression of numerous genes. Considering multiple targets of vitamin $\mathrm{D}$, we propose that pleiotropic action of vitamin $\mathrm{D}$ is a result of the crosstalk between insulin signaling and other signaling pathways governing metabolism, inflammation, immunomodulation, apoptosis, and adipogenesis. We have only just started to understand how vitamin D reduces insulin resistance and associated disorders. However, we would like to underline that although the awareness of vitamin D-associated health benefits is arising, the elevated consumption of vitamin D supplements may predispose to an increased incidence of vitamin D toxicity. Thus, without medical supervision, we advise caution for people who self-administrate higher than recommended doses of vitamin D.

Author Contributions: Conceptualization, I.S.-P. and A.Ś.; methodology, I.S.-P. and A.Ś.; visualization, I.S.-P.; writing —original draft, I.S.-P.; writing—review and editing, A.S. and J.D.; funding acquisition A.S. and J.D. All authors have read and agreed to the published version of the manuscript.

Funding: This paper was supported by the grant from Medical University of Lodz (No. 503/1-159-01/503-21-001) and Polish Society of Metabolic Disorders.

Conflicts of Interest: The authors declare no conflict of interest.

\section{References}

1. Wang, H.; Chen, W.; Li, D.; Yin, X.; Zhang, X.; Olsen, N.; Zheng, S.G. Vitamin D and Chronic Diseases. Aging Dis. 2017, 8, 346-353. [CrossRef]

2. Berridge, M.J. Vitamin D deficiency and diabetes. Biochem. J. 2017, 474, 1321-1332. [CrossRef] [PubMed]

3. Al-Shoumer, K.A.; Al-Essa, T.M. Is there a relationship between vitamin D with insulin resistance and diabetes mellitus? World J. Diabetes 2015, 6, 1057-1064. [CrossRef] [PubMed]

4. Tao, S.; Yuan, Q.; Mao, L.; Chen, F.-L.; Ji, F.; Cui, Z.-H. Vitamin D deficiency causes insulin resistance by provoking oxidative stress in hepatocytes. Oncotarget 2017, 8, 67605-67613. [CrossRef] [PubMed]

5. Wenclewska, S.; Szymczak-Pajor, I.; Drzewoski, J.; Bunk, M.; Śliwińska, A. Vitamin D Supplementation Reduces Both Oxidative DNA Damage and Insulin Resistance in the Elderly with Metabolic Disorders. Int. J. Mol. Sci. 2019, 20, 2891. [CrossRef] [PubMed] 
6. Upreti, V.; Maitri, V.; Dhull, P.; Handa, A.; Prakash, M.S.; Behl, A. Effect of oral vitamin D supplementation on glycemic control in patients with type 2 diabetes mellitus with coexisting hypovitaminosis D: A parellel group placebo controlled randomized controlled pilot study. Diabetes Metab. Syndr. 2018, 12, 509-512. [CrossRef]

7. Mirhosseini, N.; Vatanparast, H.; Mazidi, M.; Kimball, S.M. The Effect of Improved Serum 25-Hydroxyvitamin D Status on Glycemic Control in Diabetic Patients: A Meta-Analysis. J. Clin. Endocrinol. Metab. 2017, 102, 3097-3110. [CrossRef]

8. Tabesh, M.; Azadbakht, L.; Faghihimani, E.; Tabesh, M.; Esmaillzadeh, A. Effects of calcium-vitamin D co-supplementation on metabolic profiles in vitamin D insufficient people with type 2 diabetes: A randomised controlled clinical trial. Diabetologia 2014, 57, 2038-2047. [CrossRef]

9. El Hajj, C.; Chardigny, J.-M.; Boirie, Y.; Yammine, K.; Helou, M.; Walrand, S. Effect of Vitamin D Treatment on Glucose Homeostasis and Metabolism in Lebanese Older Adults: A Randomized Controlled Trial. J. Nutr. Health Aging 2018, 22, 1128-1132. [CrossRef]

10. Barzegari, M.; Sarbakhsh, P.; Mobasseri, M.; Noshad, H.; Esfandiari, A.; Khodadadi, B.; Gargari, B.P. The effects of vitamin D supplementation on lipid profiles and oxidative indices among diabetic nephropathy patients with marginal vitamin D status. Diabetes Metab. Syndr. 2019, 13, 542-547. [CrossRef]

11. Abbas, M.A. Physiological functions of Vitamin D in adipose tissue. J. Steroid. Biochem. Mol. Biol. 2017, 165, 369-381. [CrossRef] [PubMed]

12. Ceglia, L. Vitamin D and Its Role in Skeletal Muscle. Curr. Opin. Clin. Nutr. Metab. Care 2009, 12, 628-633. [CrossRef] [PubMed]

13. Bischoff, H.A.; Borchers, M.; Gudat, F.; Duermueller, U.; Theiler, R.; Stähelin, H.B.; Dick, W. In situ detection of 1,25-dihydroxyvitamin $\mathrm{D}_{3}$ receptor in human skeletal muscle tissue. Histochem. J. 2001, 33, 19-24. [CrossRef] [PubMed]

14. Ding, N.; Liddle, C.; Evans, R.M.; Downes, M. Hepatic actions of Vitamin D receptor ligands: An unexpected solution to chronic liver disease? Expert Rev. Clin. Pharmacol. 2013, 6, 597-599. [CrossRef] [PubMed]

15. Wimalawansa, S.J. Associations of vitamin D with insulin resistance, obesity, type 2 diabetes, and metabolic syndrome. J. Steroid. Biochem. Mol. Biol. 2018, 175, 177-189. [CrossRef]

16. Leung, P.S. The Potential Protective Action of Vitamin D in Hepatic Insulin Resistance and Pancreatic Islet Dysfunction in Type 2 Diabetes Mellitus. Nutrients 2016, 8, 147. [CrossRef]

17. Benetti, E.; Mastrocola, R.; Chiazza, F.; Nigro, D.; D'Antona, G.; Bordano, V.; Fantozzi, R.; Aragno, M.; Collino, M.; Minetto, M.A. Effects of vitamin D on insulin resistance and myosteatosis in diet-induced obese mice. PLoS ONE 2018, 13, e0189707. [CrossRef]

18. Lerchbaum, E.; Trummer, C.; Theiler-Schwetz, V.; Kollmann, M.; Wölfler, M.; Pilz, S.; Obermayer-Pietsch, B. Effects of Vitamin D Supplementation on Body Composition and Metabolic Risk Factors in Men: A Randomized Controlled Trial. Nutrients 2019, 11, 1894. [CrossRef]

19. Forouhi, N.G.; Menon, R.K.; Sharp, S.J.; Mannan, N.; Timms, P.M.; Martineau, A.R.; Rickard, A.P.; Boucher, B.J.; Chowdhury, T.A.; Griffiths, C.J.; et al. Effects of vitamin $\mathrm{D}_{2}$ or $\mathrm{D}_{3}$ supplementation on glycaemic control and cardiometabolic risk among people at risk of type 2 diabetes: Results of a randomized double-blind placebo-controlled trial. Diabetes Obes. Metab. 2016, 18, 392-400. [CrossRef]

20. Heshmat, R.; Tabatabaei-Malazy, O.; Abbaszadeh-Ahranjani, S.; Shahbazi, S.; Khooshehchin, G.; Bandarian, F.; Larijani, B. Effect of vitamin D on insulin resistance and anthropometric parameters in Type 2 diabetes; a randomized double-blind clinical trial. DARU J. Pharm. Sci. 2012, 20, 10. [CrossRef]

21. Davidson, M.B.; Duran, P.; Lee, M.L.; Friedman, T.C. High-dose vitamin D supplementation in people with prediabetes and hypovitaminosis D. Diabetes Care 2013, 36, 260-266. [CrossRef] [PubMed]

22. Yiu, Y.-F.; Yiu, K.-H.; Siu, C.-W.; Chan, Y.-H.; Li, S.-W.; Wong, L.-Y.; Lee, S.W.L.; Tam, S.; Wong, E.W.K.; Lau, C.-P.; et al. Randomized controlled trial of vitamin D supplement on endothelial function in patients with type 2 diabetes. Atherosclerosis 2013, 227, 140-146. [CrossRef] [PubMed]

23. Asemi, Z.; Hashemi, T.; Karamali, M.; Samimi, M.; Esmaillzadeh, A. Effects of vitamin D supplementation on glucose metabolism, lipid concentrations, inflammation, and oxidative stress in gestational diabetes: A double-blind randomized controlled clinical trial. Am. J. Clin. Nutr. 2013, 98, 1425-1432. [CrossRef] [PubMed]

24. Heaney, R.P. Vitamin D in health and disease. Clin. J. Am. Soc. Nephrol. 2008, 3, 1535-1541. [CrossRef] [PubMed] 
25. Jäpelt, R.B.; Jakobsen, J. Vitamin D in plants: A review of occurrence, analysis, and biosynthesis. Front. Plant. Sci. 2013, 4, 136. [CrossRef] [PubMed]

26. Schuster, I. Cytochromes P450 are essential players in the vitamin D signaling system. Biochim. Biophys. Acta 2011, 1814, 186-199. [CrossRef]

27. Jones, G.; Prosser, D.E.; Kaufmann, M. Cytochrome P450-mediated metabolism of vitamin D. J. Lipid Res. 2014, 55, 13-31. [CrossRef]

28. Holick, M.F.; Matsuoka, L.Y.; Wortsman, J. Age, vitamin D, and solar ultraviolet. Lancet 1989, 2, 1104-1105. [CrossRef]

29. Szymczak, I.; Pawliczak, R. The Active Metabolite of Vitamin $\mathrm{D}_{3}$ as a Potential Immunomodulator. Scand. J. Immunol. 2016, 83, 83-91. [CrossRef]

30. Zehnder, D.; Bland, R.; Williams, M.C.; McNinch, R.W.; Howie, A.J.; Stewart, P.M.; Hewison, M. Extrarenal expression of 25-hydroxyvitamin d(3)-1 alpha-hydroxylase. J. Clin. Endocrinol. Metab. 2001, 86, 888-894. [CrossRef]

31. Hewison, M.; Burke, F.; Evans, K.N.; Lammas, D.A.; Sansom, D.M.; Liu, P.; Modlin, R.L.; Adams, J.S. Extra-renal 25-hydroxyvitamin $\mathrm{D}_{3}$-1alpha-hydroxylase in human health and disease. J. Steroid. Biochem. Mol. Biol. 2007, 103, 316-321. [CrossRef]

32. Haussler, M.R.; Whitfield, G.K.; Kaneko, I.; Haussler, C.A.; Hsieh, D.; Hsieh, J.-C.; Jurutka, P.W. Molecular mechanisms of vitamin D action. Calcif. Tissue Int. 2013, 92, 77-98. [CrossRef] [PubMed]

33. Haussler, M.R.; Jurutka, P.W.; Mizwicki, M.; Norman, A.W. Vitamin D receptor (VDR)-mediated actions of $1 \alpha, 25(\mathrm{OH})_{2}$ vitamin $\mathrm{D}_{3}$ : Genomic and non-genomic mechanisms. Best Pract. Res. Clin. Endocrinol. Metab. 2011, 25, 543-559. [CrossRef] [PubMed]

34. Hossein-nezhad, A.; Spira, A.; Holick, M.F. Influence of Vitamin D Status and Vitamin $\mathrm{D}_{3}$ Supplementation on Genome Wide Expression of White Blood Cells: A Randomized Double-Blind Clinical Trial. PLoS ONE 2013, 8, e58725. [CrossRef] [PubMed]

35. Bikle, D. Vitamin D: Production, Metabolism, and Mechanisms of Action. In Endotext; De Groot, L.J., Chrousos, G., Dungan, K., Feingold, K.R., Grossman, A., Hershman, J.M., Koch, C., Korbonits, M., McLachlan, R., New, M., et al., Eds.; MDText.com, Inc.: South Dartmouth, MA, USA, 2000.

36. Pike, J.W.; Meyer, M.B. Fundamentals of vitamin D hormone-regulated gene expression. J. Steroid Biochem. Mol. Biol. 2014, 144, 5-11. [CrossRef]

37. Nemere, I.; Safford, S.E.; Rohe, B.; DeSouza, M.M.; Farach-Carson, M.C. Identification and characterization of $1,25 \mathrm{D}_{3}$-membrane-associated rapid response, steroid (1,25 $\mathrm{D}_{3}$-MARRS) binding protein. J. Steroid Biochem. Mol. Biol. 2004, 89-90, 281-285. [CrossRef]

38. Hii, C.S.; Ferrante, A. The Non-Genomic Actions of Vitamin, D. Nutrients 2016, 8, 135. [CrossRef]

39. Bikle, D.D. Vitamin D Metabolism, Mechanism of Action, and Clinical Applications. Chem. Biol. 2014, 21, 319-329. [CrossRef]

40. Jones, G.; Prosser, D.E.; Kaufmann, M. 25-Hydroxyvitamin D-24-hydroxylase (CYP24A1): Its important role in the degradation of vitamin D. Arch. Biochem. Biophys. 2012, 523, 9-18. [CrossRef]

41. Zierold, C.; Darwish, H.M.; DeLuca, H.F. Two vitamin D response elements function in the rat 1,25-dihydroxyvitamin D 24-hydroxylase promoter. J. Biol. Chem. 1995, 270, 1675-1678. [CrossRef]

42. Meyer, M.B.; Goetsch, P.D.; Pike, J.W. A downstream intergenic cluster of regulatory enhancers contributes to the induction of CYP24A1 expression by 1alpha,25-dihydroxyvitamin $\mathrm{D}_{3}$. J. Biol. Chem. 2010, 285, 15599-15610. [CrossRef]

43. Kim, M.-S.; Fujiki, R.; Kitagawa, H.; Kato, S. 1alpha, $25(\mathrm{OH})_{2} \mathrm{D}_{3}$-induced DNA methylation suppresses the human CYP27B1 gene. Mol. Cell. Endocrinol. 2007, 265-266, 168-173. [CrossRef] [PubMed]

44. Khundmiri, S.J.; Murray, R.D.; Lederer, E. PTH and Vitamin D. Compr. Physiol. 2016, 6, 561-601. [CrossRef] [PubMed]

45. Martin, A.; David, V.; Quarles, L.D. Regulation and function of the FGF23/klotho endocrine pathways. Physiol. Rev. 2012, 92, 131-155. [CrossRef] [PubMed]

46. Bergwitz, C.; Jüppner, H. Regulation of phosphate homeostasis by PTH, vitamin D, and FGF23. Annu. Rev. Med. 2010, 61, 91-104. [CrossRef]

47. Perwad, F.; Zhang, M.Y.H.; Tenenhouse, H.S.; Portale, A.A. Fibroblast growth factor 23 impairs phosphorus and vitamin D metabolism in vivo and suppresses 25-hydroxyvitamin D-1alpha-hydroxylase expression in vitro. Am. J. Physiol. Renal Physiol. 2007, 293, F1577-F1583. [CrossRef] 
48. Perwad, F.; Azam, N.; Zhang, M.Y.H.; Yamashita, T.; Tenenhouse, H.S.; Portale, A.A. Dietary and serum phosphorus regulate fibroblast growth factor 23 expression and 1,25-dihydroxyvitamin D metabolism in mice. Endocrinology 2005, 146, 5358-5364. [CrossRef]

49. Shimada, T.; Yamazaki, Y.; Takahashi, M.; Hasegawa, H.; Urakawa, I.; Oshima, T.; Ono, K.; Kakitani, M.; Tomizuka, K.; Fujita, T.; et al. Vitamin D receptor-independent FGF23 actions in regulating phosphate and vitamin D metabolism. Am. J. Physiol. Renal Physiol. 2005, 289, F1088-F1095. [CrossRef]

50. Rost, C.R.; Bikle, D.D.; Kaplan, R.A. In vitro stimulation of 25-hydroxycholecalciferol 1 alpha-hydroxylation by parathyroid hormone in chick kidney slices: Evidence for a role for adenosine 3',5'-monophosphate. Endocrinology 1981, 108, 1002-1006. [CrossRef]

51. Zierold, C.; Nehring, J.A.; DeLuca, H.F. Nuclear receptor 4A2 and C/EBPbeta regulate the parathyroid hormone-mediated transcriptional regulation of the 25-hydroxyvitamin $\mathrm{D}_{3}$-1alpha-hydroxylase. Arch. Biochem. Biophys. 2007, 460, 233-239. [CrossRef]

52. Zierold, C.; Mings, J.A.; DeLuca, H.F. Parathyroid hormone regulates 25-hydroxyvitamin D(3)-24-hydroxylase mRNA by altering its stability. Proc. Natl. Acad. Sci. USA 2001, 98, 13572-13576. [CrossRef] [PubMed]

53. Zierold, C.; Reinholz, G.G.; Mings, J.A.; Prahl, J.M.; DeLuca, H.F. Regulation of the procine 1,25-dihydroxyvitamin $\mathrm{D}_{3}$-24-hydroxylase (CYP24) by 1,25-dihydroxyvitamin $\mathrm{D}_{3}$ and parathyroid hormone in AOK-B50 cells. Arch. Biochem. Biophys. 2000, 381, 323-327. [CrossRef] [PubMed]

54. Riccardi, D.; Brown, E.M. Physiology and pathophysiology of the calcium-sensing receptor in the kidney. Am. J. Physiol. Renal Physiol. 2010, 298, F485-F499. [CrossRef] [PubMed]

55. Dawson-Hughes, B.; Heaney, R.P.; Holick, M.F.; Lips, P.; Meunier, P.J.; Vieth, R. Estimates of optimal vitamin D status. Osteoporos. Int. 2005, 16, 713-716. [CrossRef]

56. Holick, M.F. Vitamin D status: Measurement, interpretation, and clinical application. Ann. Epidemiol. 2009, 19, 73-78. [CrossRef]

57. Pilz, S.; Zittermann, A.; Trummer, C.; Theiler-Schwetz, V.; Lerchbaum, E.; Keppel, M.H.; Grübler, M.R.; März, W.; Pandis, M. Vitamin D testing and treatment: A narrative review of current evidence. Endocr. Connect. 2019, 8, R27-R43. [CrossRef]

58. Maretzke, F.; Bechthold, A.; Egert, S.; Ernst, J.B.; Melo van Lent, D.; Pilz, S.; Reichrath, J.; Stangl, G.I.; Stehle, P.; Volkert, D.; et al. Role of Vitamin D in Preventing and Treating Selected Extraskeletal Diseases-An Umbrella Review. Nutrients 2020, 12, 969. [CrossRef]

59. Marcinowska-Suchowierska, E.; Kupisz-Urbańska, M.; Łukaszkiewicz, J.; Płudowski, P.; Jones, G. Vitamin D Toxicity-A Clinical Perspective. Front. Endocrinol. 2018, 9, 550. [CrossRef]

60. Carmo, L.S.; Burdmann, E.A.; Fessel, M.R.; Almeida, Y.E.; Pescatore, L.A.; Farias-Silva, E.; Gamarra, L.F.; Lopes, G.H.; Aloia, T.P.A.; Liberman, M. Expansive Vascular Remodeling and Increased Vascular Calcification Response to Cholecalciferol in a Murine Model of Obesity and Insulin Resistance. Arterioscler. Thromb. Vasc. Biol. 2019, 39, 200-211. [CrossRef]

61. Holick, M.F. Vitamin D deficiency. N. Engl. J. Med. 2007, 357, 266-281. [CrossRef]

62. Hollis, B.W.; Wagner, C.L. Vitamin D requirements during lactation: High-dose maternal supplementation as therapy to prevent hypovitaminosis $\mathrm{D}$ for both the mother and the nursing infant. Am. J. Clin. Nutr. 2004, 80, 1752S-1758S. [CrossRef] [PubMed]

63. Hollis, B.W.; Wagner, C.L. Assessment of dietary vitamin D requirements during pregnancy and lactation. Am. J. Clin. Nutr. 2004, 79, 717-726. [CrossRef] [PubMed]

64. Aris, R.M.; Merkel, P.A.; Bachrach, L.K.; Borowitz, D.S.; Boyle, M.P.; Elkin, S.L.; Guise, T.A.; Hardin, D.S.; Haworth, C.S.; Holick, M.F.; et al. Guide to bone health and disease in cystic fibrosis. J. Clin. Endocrinol. Metab. 2005, 90, 1888-1896. [CrossRef]

65. Lo, C.W.; Paris, P.W.; Clemens, T.L.; Nolan, J.; Holick, M.F. Vitamin D absorption in healthy subjects and in patients with intestinal malabsorption syndromes. Am. J. Clin. Nutr. 1985, 42, 644-649. [CrossRef] [PubMed]

66. Odes, H.S.; Fraser, G.M.; Krugliak, P.; Lamprecht, S.A.; Shany, S. Effect of cimetidine on hepatic vitamin D metabolism in humans. Digestion 1990, 46, 61-64. [CrossRef]

67. Ramsay, R.E.; Slater, J.D. Effects of antiepileptic drugs on hormones. Epilepsia 1991, 32 (Suppl. S6), S60-S67. [CrossRef]

68. Rejnmark, L.; Vestergaard, P.; Heickendorff, L.; Andreasen, F.; Mosekilde, L. Effects of thiazideand loop-diuretics, alone or in combination, on calcitropic hormones and biochemical bone markers: A randomized controlled study. J. Intern. Med. 2001, 250, 144-153. [CrossRef] 
69. Rosenblatt, S.; Chanley, J.D.; Segal, R.L. The effect of lithium on vitamin D metabolism. Biol. Psychiatry 1989, 26, 206-208. [CrossRef]

70. Samuel, V.T.; Shulman, G.I. Mechanisms for insulin resistance: Common threads and missing links. Cell 2012, 148, 852-871. [CrossRef]

71. Goldstein, B.J. Protein-tyrosine phosphatase 1B (PTP1B): A novel therapeutic target for type 2 diabetes mellitus, obesity and related states of insulin resistance. Curr. Drug Targets Immune Endocr. Metabol. Disord. 2001, 1, 265-275. [CrossRef]

72. White, M.F.; Yenush, L. The IRS-signaling system: A network of docking proteins that mediate insulin and cytokine action. Curr. Top. Microbiol. Immunol. 1998, 228, 179-208.

73. Taniguchi, C.M.; Emanuelli, B.; Kahn, C.R. Critical nodes in signalling pathways: Insights into insulin action. Nat. Rev. Mol. Cell Biol. 2006, 7, 85-96. [CrossRef]

74. Alessi, D.R.; James, S.R.; Downes, C.P.; Holmes, A.B.; Gaffney, P.R.; Reese, C.B.; Cohen, P. Characterization of a 3-phosphoinositide-dependent protein kinase which phosphorylates and activates protein kinase Balpha. Curr. Biol. 1997, 7, 261-269. [CrossRef]

75. Le Good, J.A.; Ziegler, W.H.; Parekh, D.B.; Alessi, D.R.; Cohen, P.; Parker, P.J. Protein kinase C isotypes controlled by phosphoinositide 3-kinase through the protein kinase PDK1. Science 1998, 281, 2042-2045. [CrossRef] [PubMed]

76. Song, G.; Ouyang, G.; Bao, S. The activation of Akt/PKB signaling pathway and cell survival. J. Cell. Mol. Med. 2005, 9, 59-71. [CrossRef] [PubMed]

77. Strycharz, J.; Drzewoski, J.; Szemraj, J.; Sliwinska, A. Is p53 Involved in Tissue-Specific Insulin Resistance Formation? Oxid. Med. Cell. Longev. 2017, 2017, 9270549. [CrossRef]

78. Liang, F.; Kume, S.; Koya, D. SIRT1 and insulin resistance. Nat. Rev. Endocrinol. 2009, 5, 367-373. [CrossRef] [PubMed]

79. Saltiel, A.R.; Kahn, C.R. Insulin signalling and the regulation of glucose and lipid metabolism. Nature 2001, 414, 799-806. [CrossRef] [PubMed]

80. Chang, Y.-C.; Chuang, L.-M. The role of oxidative stress in the pathogenesis of type 2 diabetes: From molecular mechanism to clinical implication. Am. J. Transl. Res. 2010, 2, 316-331.

81. Petersen, K.F.; Shulman, G.I. Etiology of insulin resistance. Am. J. Med. 2006, 119, S10-S16. [CrossRef]

82. Griffin, M.E.; Marcucci, M.J.; Cline, G.W.; Bell, K.; Barucci, N.; Lee, D.; Goodyear, L.J.; Kraegen, E.W.; White, M.F.; Shulman, G.I. Free fatty acid-induced insulin resistance is associated with activation of protein kinase $C$ theta and alterations in the insulin signaling cascade. Diabetes 1999, 48, 1270-1274. [CrossRef]

83. Kim, J.K.; Fillmore, J.J.; Sunshine, M.J.; Albrecht, B.; Higashimori, T.; Kim, D.-W.; Liu, Z.-X.; Soos, T.J.; Cline, G.W.; O'Brien, W.R.; et al. PKC-theta knockout mice are protected from fat-induced insulin resistance. J. Clin. Investig. 2004, 114, 823-827. [CrossRef] [PubMed]

84. Li, Y.; Soos, T.J.; Li, X.; Wu, J.; Degennaro, M.; Sun, X.; Littman, D.R.; Birnbaum, M.J.; Polakiewicz, R.D. Protein kinase C Theta inhibits insulin signaling by phosphorylating IRS1 at Ser(1101). J. Biol. Chem. 2004, 279, 45304-45307. [CrossRef] [PubMed]

85. Shulman, G.I. Ectopic fat in insulin resistance, dyslipidemia, and cardiometabolic disease. N. Engl. J. Med. 2014, 371, 2237-2238. [CrossRef] [PubMed]

86. Rondinone, C.M.; Wang, L.M.; Lonnroth, P.; Wesslau, C.; Pierce, J.H.; Smith, U. Insulin receptor substrate (IRS) 1 is reduced and IRS-2 is the main docking protein for phosphatidylinositol 3-kinase in adipocytes from subjects with non-insulin-dependent diabetes mellitus. Proc. Natl. Acad. Sci. USA 1997, 94, 4171-4175. [CrossRef]

87. Shepherd, P.R.; Kahn, B.B. Glucose transporters and insulin action-implications for insulin resistance and diabetes mellitus. N. Engl. J. Med. 1999, 341, 248-257. [CrossRef]

88. Penkov, D.N.; Egorov, A.D.; Mozgovaya, M.N.; Tkachuk, V.A. Insulin resistance and adipogenesis: Role of transcription and secreted factors. Biochem. Mosc. 2013, 78, 8-18. [CrossRef]

89. Galic, S.; Oakhill, J.S.; Steinberg, G.R. Adipose tissue as an endocrine organ. Mol. Cell. Endocrinol. 2010, 316, 129-139. [CrossRef]

90. Cawthorn, W.P.; Sethi, J.K. TNF- $\alpha$ and adipocyte biology. FEBS Lett. 2008, 582, 117-131. [CrossRef]

91. Weisberg, S.P.; McCann, D.; Desai, M.; Rosenbaum, M.; Leibel, R.L.; Ferrante, A.W. Obesity is associated with macrophage accumulation in adipose tissue. J. Clin. Investig. 2003, 112, 1796-1808. [CrossRef] 
92. Ross, S.E.; Erickson, R.L.; Gerin, I.; DeRose, P.M.; Bajnok, L.; Longo, K.A.; Misek, D.E.; Kuick, R.; Hanash, S.M.; Atkins, K.B.; et al. Microarray analyses during adipogenesis: Understanding the effects of Wnt signaling on adipogenesis and the roles of liver X receptor alpha in adipocyte metabolism. Mol. Cell. Biol. 2002, 22, 5989-5999. [CrossRef]

93. Fain, J.N.; Bahouth, S.W.; Madan, A.K. TNFalpha release by the nonfat cells of human adipose tissue. Int. J. Obes. Relat. Metab. Disord. 2004, 28, 616-622. [CrossRef] [PubMed]

94. Xu, H.; Barnes, G.T.; Yang, Q.; Tan, G.; Yang, D.; Chou, C.J.; Sole, J.; Nichols, A.; Ross, J.S.; Tartaglia, L.A.; et al. Chronic inflammation in fat plays a crucial role in the development of obesity-related insulin resistance. J. Clin. Investig. 2003, 112, 1821-1830. [CrossRef]

95. Hotamisligil, G.S. The role of TNFalpha and TNF receptors in obesity and insulin resistance. J. Intern. Med. 1999, 245, 621-625. [CrossRef] [PubMed]

96. Peraldi, P.; Spiegelman, B. TNF-alpha and insulin resistance: Summary and future prospects. Mol. Cell. Biochem. 1998, 182, 169-175. [CrossRef] [PubMed]

97. Galicia-Garcia, U.; Benito-Vicente, A.; Jebari, S.; Larrea-Sebal, A.; Siddiqi, H.; Uribe, K.B.; Ostolaza, H.; Martín, C. Pathophysiology of Type 2 Diabetes Mellitus. Int. J. Mol. Sci 2020, 21, 6275. [CrossRef]

98. Kim, J.B.; Sarraf, P.; Wright, M.; Yao, K.M.; Mueller, E.; Solanes, G.; Lowell, B.B.; Spiegelman, B.M. Nutritional and insulin regulation of fatty acid synthetase and leptin gene expression through ADD1/SREBP1. J. Clin. Investig. 1998, 101, 1-9. [CrossRef]

99. Bakan, I.; Laplante, M. Connecting mTORC1 signaling to SREBP-1 activation. Curr. Opin. Lipidol. 2012, 23, 226-234. [CrossRef]

100. Horton, J.D.; Goldstein, J.L.; Brown, M.S. SREBPs: Activators of the complete program of cholesterol and fatty acid synthesis in the liver. J. Clin. Investig. 2002, 109, 1125-1131. [CrossRef]

101. Kim, J.J.; Li, P.; Huntley, J.; Chang, J.P.; Arden, K.C.; Olefsky, J.M. FoxO1 haploinsufficiency protects against high-fat diet-induced insulin resistance with enhanced peroxisome proliferator-activated receptor gamma activation in adipose tissue. Diabetes 2009, 58, 1275-1282. [CrossRef]

102. Tontonoz, P.; Spiegelman, B.M. Fat and beyond: The diverse biology of PPARgamma. Annu. Rev. Biochem. 2008, 77, 289-312. [CrossRef] [PubMed]

103. Armoni, M.; Harel, C.; Karni, S.; Chen, H.; Bar-Yoseph, F.; Ver, M.R.; Quon, M.J.; Karnieli, E. FOXO1 represses peroxisome proliferator-activated receptor-gamma1 and -gamma2 gene promoters in primary adipocytes. A novel paradigm to increase insulin sensitivity. J. Biol. Chem. 2006, 281, 19881-19891. [CrossRef] [PubMed]

104. Gilon, P.; Chae, H.-Y.; Rutter, G.A.; Ravier, M.A. Calcium signaling in pancreatic $\beta$-cells in health and in Type 2 diabetes. Cell Calcium 2014, 56, 340-361. [CrossRef] [PubMed]

105. Cade, C.; Norman, A.W. Vitamin $\mathrm{D}_{3}$ improves impaired glucose tolerance and insulin secretion in the vitamin D-deficient rat in vivo. Endocrinology 1986, 119, 84-90. [CrossRef] [PubMed]

106. Chertow, B.S.; Sivitz, W.I.; Baranetsky, N.G.; Clark, S.A.; Waite, A.; Deluca, H.F. Cellular mechanisms of insulin release: The effects of vitamin D deficiency and repletion on rat insulin secretion. Endocrinology 1983, 113, 1511-1518. [CrossRef]

107. Norman, A.W.; Frankel, J.B.; Heldt, A.M.; Grodsky, G.M. Vitamin D deficiency inhibits pancreatic secretion of insulin. Science 1980, 209, 823-825. [CrossRef]

108. Tanaka, Y.; Seino, Y.; Ishida, M.; Yamaoka, K.; Yabuuchi, H.; Ishida, H.; Seino, S.; Seino, Y.; Imura, H. Effect of vitamin $\mathrm{D}_{3}$ on the pancreatic secretion of insulin and somatostatin. Acta Endocrinol. 1984, 105, 528-533. [CrossRef]

109. Kadowaki, S.; Norman, A.W. Dietary vitamin D is essential for normal insulin secretion from the perfused rat pancreas. J. Clin. Investig. 1984, 73, 759-766. [CrossRef]

110. Mitri, J.; Pittas, A.G. Vitamin D and diabetes. Endocrinol. Metab. Clin. N. Am. 2014, 43, 205-232. [CrossRef]

111. Inomata, S.; Kadowaki, S.; Yamatani, T.; Fukase, M.; Fujita, T. Effect of 1 alpha (OH)-vitamin $D_{3}$ on insulin secretion in diabetes mellitus. Bone Miner. 1986, 1, 187-192.

112. Boucher, B.J.; Mannan, N.; Noonan, K.; Hales, C.N.; Evans, S.J. Glucose intolerance and impairment of insulin secretion in relation to vitamin D deficiency in east London Asians. Diabetologia 1995, 38, 1239-1245. [CrossRef] [PubMed]

113. Johnson, J.A.; Grande, J.P.; Roche, P.C.; Kumar, R. Immunohistochemical localization of the $1,25(\mathrm{OH})_{2} \mathrm{D}_{3}$ receptor and calbindin D28k in human and rat pancreas. Am. J. Physiol. 1994, 267, E356-E360. [CrossRef] [PubMed] 
114. Borissova, A.M.; Tankova, T.; Kirilov, G.; Dakovska, L.; Kovacheva, R. The effect of vitamin $\mathrm{D}_{3}$ on insulin secretion and peripheral insulin sensitivity in type 2 diabetic patients. Int. J. Clin. Pract. 2003, 57, 258-261. [PubMed]

115. Nyomba, B.L.; Auwerx, J.; Bormans, V.; Peeters, T.L.; Pelemans, W.; Reynaert, J.; Bouillon, R.; Vantrappen, G.; De Moor, P. Pancreatic secretion in man with subclinical vitamin D deficiency. Diabetologia 1986, 29, 34-38. [CrossRef]

116. Altieri, B.; Grant, W.B.; Della Casa, S.; Orio, F.; Pontecorvi, A.; Colao, A.; Sarno, G.; Muscogiuri, G. Vitamin D and pancreas: The role of sunshine vitamin in the pathogenesis of diabetes mellitus and pancreatic cancer. Crit. Rev. Food Sci. Nutr. 2017, 57, 3472-3488. [CrossRef]

117. Doyle, M.E.; Egan, J.M. Pharmacological agents that directly modulate insulin secretion. Pharmacol. Rev. 2003, 55, 105-131. [CrossRef]

118. Santos, G.J.; dos Ferreira, S.M.; Ortis, F.; Rezende, L.F.; Li, C.; Naji, A.; Carneiro, E.M.; Kaestner, K.H.; Boschero, A.C. Metabolic memory of $\mathrm{B}$-cells controls insulin secretion and is mediated by CaMKII. Mol. Metab. 2014, 3, 484-489. [CrossRef]

119. Dalle, S.; Quoyer, J.; Varin, E.; Costes, S. Roles and regulation of the transcription factor CREB in pancreatic $\beta$-cells. Curr. Mol. Pharmacol. 2011, 4, 187-195. [CrossRef]

120. Sooy, K.; Schermerhorn, T.; Noda, M.; Surana, M.; Rhoten, W.B.; Meyer, M.; Fleischer, N.; Sharp, G.W.; Christakos, S. Calbindin- $\mathrm{D}(28 \mathrm{k})$ controls $[\mathrm{Ca}(2+)](\mathrm{i})$ and insulin release. Evidence obtained from calbindin-d(28k) knockout mice and beta cell lines. J. Biol. Chem. 1999, 274, 34343-34349. [CrossRef]

121. Wasserman, R.H. Vitamin D and the dual processes of intestinal calcium absorption. J. Nutr. 2004, 134, 3137-3139. [CrossRef]

122. Viragh, P.A.; de Haglid, K.G.; Celio, M.R. Parvalbumin increases in the caudate putamen of rats with vitamin D hypervitaminosis. Proc. Natl. Acad. Sci. USA 1989, 86, 3887-3890. [CrossRef] [PubMed]

123. Bouillon, R.; Carmeliet, G.; Verlinden, L.; van Etten, E.; Verstuyf, A.; Luderer, H.F.; Lieben, L.; Mathieu, C.; Demay, M. Vitamin D and human health: Lessons from vitamin D receptor null mice. Endocr. Rev. 2008, 29, 726-776. [CrossRef] [PubMed]

124. Ni, Z.; Smogorzewski, M.; Massry, S.G. Effects of parathyroid hormone on cytosolic calcium of rat adipocytes. Endocrinology 1994, 135, 1837-1844. [CrossRef] [PubMed]

125. Baczynski, R.; Massry, S.G.; Magott, M.; el-Belbessi, S.; Kohan, R.; Brautbar, N. Effect of parathyroid hormone on energy metabolism of skeletal muscle. Kidney Int. 1985, 28, 722-727. [CrossRef] [PubMed]

126. Reusch, J.E.; Begum, N.; Sussman, K.E.; Draznin, B. Regulation of GLUT-4 phosphorylation by intracellular calcium in adipocytes. Endocrinology 1991, 129, 3269-3273. [CrossRef]

127. Thomas, D.M.; Rogers, S.D.; Sleeman, M.W.; Pasquini, G.M.; Bringhurst, F.R.; Ng, K.W.; Zajac, J.D.; Best, J.D. Modulation of glucose transport by parathyroid hormone and insulin in UMR 106-01, a clonal rat osteogenic sarcoma cell line. J. Mol. Endocrinol. 1995, 14, 263-275. [CrossRef]

128. Teegarden, D.; Donkin, S.S. Vitamin D: Emerging new roles in insulin sensitivity. Nutr. Res. Rev. 2009, 22, 82-92. [CrossRef]

129. Sung, C.-C.; Liao, M.-T.; Lu, K.-C.; Wu, C.-C. Role of vitamin D in insulin resistance. J. Biomed. Biotechnol. 2012, 2012, 634195. [CrossRef]

130. Chiu, K.C.; Chuang, L.M.; Lee, N.P.; Ryu, J.M.; McGullam, J.L.; Tsai, G.P.; Saad, M.F. Insulin sensitivity is inversely correlated with plasma intact parathyroid hormone level. Metab. Clin. Exp. 2000, 49, 1501-1505. [CrossRef]

131. Reis, J.P.; von Mühlen, D.; Kritz-Silverstein, D.; Wingard, D.L.; Barrett-Connor, E. Vitamin D, parathyroid hormone levels, and the prevalence of metabolic syndrome in community-dwelling older adults. Diabetes Care 2007, 30, 1549-1555. [CrossRef]

132. Wright, D.C.; Hucker, K.A.; Holloszy, J.O.; Han, D.H. Ca ${ }^{2+}$ and AMPK both mediate stimulation of glucose transport by muscle contractions. Diabetes 2004, 53, 330-335. [CrossRef] [PubMed]

133. Muscogiuri, G.; Chavez, A.O.; Gastaldelli, A.; Perego, L.; Tripathy, D.; Saad, M.J.; Velloso, L.; Folli, F. The crosstalk between insulin and renin-angiotensin-aldosterone signaling systems and its effect on glucose metabolism and diabetes prevention. Curr. Vasc. Pharmacol. 2008, 6, 301-312. [CrossRef] [PubMed]

134. Wei, Y.; Sowers, J.R.; Clark, S.E.; Li, W.; Ferrario, C.M.; Stump, C.S. Angiotensin II-induced skeletal muscle insulin resistance mediated by NF-kappaB activation via NADPH oxidase. Am. J. Physiol. Endocrinol. Metab. 2008, 294, E345-E351. [CrossRef] [PubMed] 
135. Yuan, W.; Pan, W.; Kong, J.; Zheng, W.; Szeto, F.L.; Wong, K.E.; Cohen, R.; Klopot, A.; Zhang, Z.; Li, Y.C. 1,25-dihydroxyvitamin $\mathrm{D}_{3}$ suppresses renin gene transcription by blocking the activity of the cyclic AMP response element in the renin gene promoter. J. Biol. Chem. 2007, 282, 29821-29830. [CrossRef]

136. Kong, J.; Li, Y.C. Effect of ANG II type I receptor antagonist and ACE inhibitor on vitamin D receptor-null mice. Am. J. Physiol. Regul. Integr. Comp. Physiol. 2003, 285, R255-R261. [CrossRef]

137. Li, Y.C.; Kong, J.; Wei, M.; Chen, Z.-F.; Liu, S.Q.; Cao, L.-P. 1,25-Dihydroxyvitamin D(3) is a negative endocrine regulator of the renin-angiotensin system. J. Clin. Investig. 2002, 110, 229-238. [CrossRef]

138. Angellotti, E.; Pittas, A.G. The Role of Vitamin D in the Prevention of Type 2 Diabetes: To D or Not to D? Endocrinology 2017, 158, 2013-2021. [CrossRef]

139. Simpson, R.U.; Thomas, G.A.; Arnold, A.J. Identification of 1,25-dihydroxyvitamin $\mathrm{D}_{3}$ receptors and activities in muscle. J. Biol. Chem. 1985, 260, 8882-8891.

140. Maestro, B.; Campión, J.; Dávila, N.; Calle, C. Stimulation by 1,25-dihydroxyvitamin $\mathrm{D}_{3}$ of insulin receptor expression and insulin responsiveness for glucose transport in U-937 human promonocytic cells. Endocr. J. 2000, 47, 383-391. [CrossRef]

141. Dunlop, T.W.; Väisänen, S.; Frank, C.; Molnár, F.; Sinkkonen, L.; Carlberg, C. The human peroxisome proliferator-activated receptor delta gene is a primary target of 1alpha,25-dihydroxyvitamin $\mathrm{D}_{3}$ and its nuclear receptor. J. Mol. Biol. 2005, 349, 248-260. [CrossRef]

142. Manna, P.; Achari, A.E.; Jain, S.K. 1,25(OH) $)_{2}$-vitamin $\mathrm{D}_{3}$ upregulates glucose uptake mediated by SIRT1/IRS1/GLUT4 signaling cascade in $\mathrm{C}_{2} \mathrm{C}_{12}$ myotubes. Mol. Cell. Biochem. 2018, 444, 103-108. [CrossRef] [PubMed]

143. Bland, R.; Markovic, D.; Hills, C.E.; Hughes, S.V.; Chan, S.L.F.; Squires, P.E.; Hewison, M. Expression of 25-hydroxyvitamin $\mathrm{D}_{3}-1$ alpha-hydroxylase in pancreatic islets. J. Steroid Biochem. Mol. Biol. 2004, 89-90, 121-125. [CrossRef]

144. Zeitz, U.; Weber, K.; Soegiarto, D.W.; Wolf, E.; Balling, R.; Erben, R.G. Impaired insulin secretory capacity in mice lacking a functional vitamin D receptor. FASEB J. 2003, 17, 509-511. [CrossRef] [PubMed]

145. Maestro, B.; Molero, S.; Bajo, S.; Dávila, N.; Calle, C. Transcriptional activation of the human insulin receptor gene by 1,25-dihydroxyvitamin D(3). Cell Biochem. Funct. 2002, 20, 227-232. [CrossRef] [PubMed]

146. Green, T.J.; Skeaff, C.M.; Rockell, J.E.P.; Venn, B.J.; Lambert, A.; Todd, J.; Khor, G.L.; Loh, S.P.; Muslimatun, S.; Agustina, R.; et al. Vitamin D status and its association with parathyroid hormone concentrations in women of child-bearing age living in Jakarta and Kuala Lumpur. Eur. J. Clin. Nutr. 2008, 62, 373-378. [CrossRef]

147. Maestro, B.; Dávila, N.; Carranza, M.C.; Calle, C. Identification of a Vitamin D response element in the human insulin receptor gene promoter. J. Steroid Biochem. Mol. Biol. 2003, 84, 223-230. [CrossRef]

148. George, N.; Kumar, T.P.; Antony, S.; Jayanarayanan, S.; Paulose, C.S. Effect of vitamin $\mathrm{D}_{3}$ in reducing metabolic and oxidative stress in the liver of streptozotocin-induced diabetic rats. Br. J. Nutr. 2012, 108, 1410-1418. [CrossRef]

149. Alkharfy, K.M.; Al-Daghri, N.M.; Yakout, S.M.; Hussain, T.; Mohammed, A.K.; Krishnaswamy, S. Influence of vitamin D treatment on transcriptional regulation of insulin-sensitive genes. Metab. Syndr. Relat. Disord. 2013, 11, 283-288. [CrossRef]

150. Calle, C.; Maestro, B.; García-Arencibia, M. Genomic actions of 1,25-dihydroxyvitamin $\mathrm{D}_{3}$ on insulin receptor gene expression, insulin receptor number and insulin activity in the kidney, liver and adipose tissue of streptozotocin-induced diabetic rats. BMC Mol. Biol. 2008, 9, 65. [CrossRef]

151. Garbossa, S.G.; Folli, F. Vitamin D, sub-inflammation and insulin resistance. A window on a potential role for the interaction between bone and glucose metabolism. Rev. Endocr. Metab. Disord. 2017, 18, 243-258. [CrossRef]

152. Ježek, P.; Dlasková, A.; Plecitá-Hlavatá, L. Redox homeostasis in pancreatic $\beta$ cells. Oxid. Med. Cell. Longev. 2012, 2012, 932838. [CrossRef] [PubMed]

153. Hurrle, S.; Hsu, W.H. The etiology of oxidative stress in insulin resistance. Biomed. J. 2017, 40, $257-262$. [CrossRef] [PubMed]

154. Newsholme, P.; Keane, K.N.; Carlessi, R.; Cruzat, V. Oxidative stress pathways in pancreatic $\beta$-cells and insulin-sensitive cells and tissues: Importance to cell metabolism, function, and dysfunction. Am. J. Physiol., Cell. Physiol. 2019, 317, C420-C433. [CrossRef] [PubMed]

155. Solinas, G.; Karin, M. JNK1 and IKKbeta: Molecular links between obesity and metabolic dysfunction. FASEB J. 2010, 24, 2596-2611. [CrossRef] 
156. Henriksen, E.J.; Diamond-Stanic, M.K.; Marchionne, E.M. Oxidative Stress and the Etiology of Insulin Resistance and Type 2 Diabetes. Free Radic. Biol. Med. 2011, 51, 993-999. [CrossRef]

157. Inoguchi, T.; Li, P.; Umeda, F.; Yu, H.Y.; Kakimoto, M.; Imamura, M.; Aoki, T.; Etoh, T.; Hashimoto, T.; Naruse, M.; et al. High glucose level and free fatty acid stimulate reactive oxygen species production through protein kinase $\mathrm{C}$-dependent activation of $\mathrm{NAD}(\mathrm{P}) \mathrm{H}$ oxidase in cultured vascular cells. Diabetes 2000, 49, 1939-1945. [CrossRef]

158. Newsholme, P.; Cruzat, V.F.; Keane, K.N.; Carlessi, R.; de Bittencourt, P.I.H. Molecular mechanisms of ROS production and oxidative stress in diabetes. Biochem. J. 2016, 473, 4527-4550. [CrossRef]

159. Fridlyand, L.E.; Philipson, L.H. Reactive species and early manifestation of insulin resistance in type 2 diabetes. Diabetes Obes. Metab. 2006, 8, 136-145. [CrossRef]

160. Paolisso, G.; D'Amore, A.; Volpe, C.; Balbi, V.; Saccomanno, F.; Galzerano, D.; Giugliano, D.; Varricchio, M.; D'Onofrio, F. Evidence for a relationship between oxidative stress and insulin action in non-insulin-dependent (type II) diabetic patients. Metab. Clin. Exp. 1994, 43, 1426-1429. [CrossRef]

161. Nourooz-Zadeh, J.; Rahimi, A.; Tajaddini-Sarmadi, J.; Tritschler, H.; Rosen, P.; Halliwell, B.; Betteridge, D.J. Relationships between plasma measures of oxidative stress and metabolic control in NIDDM. Diabetologia 1997, 40, 647-653. [CrossRef]

162. Evans, J.L.; Goldfine, I.D.; Maddux, B.A.; Grodsky, G.M. Are Oxidative Stress-Activated Signaling Pathways Mediators of Insulin Resistance and $\beta$-Cell Dysfunction? Diabetes 2003, 52, 1-8. [CrossRef]

163. Brownlee, M. The Pathobiology of Diabetic Complications: A Unifying Mechanism. Diabetes 2005, 54, 1615-1625. [CrossRef]

164. Rao, M.S.; Reddy, J.K. Peroxisomal $\beta$-Oxidation and Steatohepatitis. Semin. Liver Dis. 2001, 21, $043-056$. [CrossRef]

165. Lowell, B.B.; Shulman, G.I. Mitochondrial Dysfunction and Type 2 Diabetes. Science 2005, 307, $384-387$. [CrossRef]

166. Carlsson, C.; Håkan Borg, L.A.; Welsh, N. Sodium Palmitate Induces Partial Mitochondrial Uncoupling and Reactive Oxygen Species in Rat Pancreatic Islets in Vitro. Endocrinology 1999, 140, 3422-3428. [CrossRef]

167. Scaini, G.; Rezin, G.T.; Carvalho, A.F.; Streck, E.L.; Berk, M.; Quevedo, J. Mitochondrial dysfunction in bipolar disorder: Evidence, pathophysiology and translational implications. Neurosci. Biobehav. Rev. 2016, 68, 694-713. [CrossRef]

168. Kim, H.K.; Andreazza, A.C.; Yeung, P.Y.; Isaacs-Trepanier, C.; Young, L.T. Oxidation and nitration in dopaminergic areas of the prefrontal cortex from patients with bipolar disorder and schizophrenia. J. Psychiatry Neurosci. 2014, 39, 276-285. [CrossRef]

169. Silvagno, F.; Consiglio, M.; Foglizzo, V.; Destefanis, M.; Pescarmona, G. Mitochondrial translocation of vitamin D receptor is mediated by the permeability transition pore in human keratinocyte cell line. PLoS ONE 2013, 8, e54716. [CrossRef]

170. Silvagno, F.; De Vivo, E.; Attanasio, A.; Gallo, V.; Mazzucco, G.; Pescarmona, G. Mitochondrial localization of vitamin D receptor in human platelets and differentiated megakaryocytes. PLoS ONE 2010, 5, e8670. [CrossRef]

171. Verdile, G.; Keane, K.N.; Cruzat, V.F.; Medic, S.; Sabale, M.; Rowles, J.; Wijesekara, N.; Martins, R.N.; Fraser, P.E.; Newsholme, P. Inflammation and Oxidative Stress: The Molecular Connectivity between Insulin Resistance, Obesity, and Alzheimer's Disease. Mediat. Inflamm. 2015, 2015, 105828. [CrossRef]

172. Qatanani, M.; Lazar, M.A. Mechanisms of obesity-associated insulin resistance: Many choices on the menu. Genes Dev. 2007, 21, 1443-1455. [CrossRef]

173. Rains, J.L.; Jain, S.K. Oxidative Stress, Insulin Signaling and Diabetes. Free Radic. Biol. Med. 2011, 50, 567-575. [CrossRef]

174. Ricciardi, C.J.; Bae, J.; Esposito, D.; Komarnytsky, S.; Hu, P.; Chen, J.; Zhao, L. 1,25-Dihydroxyvitamin $\mathrm{D}_{3} /$ vitamin $\mathrm{D}$ receptor suppresses brown adipocyte differentiation and mitochondrial respiration. Eur. J. Nutr. 2015, 54, 1001-1012. [CrossRef]

175. Ricca, C.; Aillon, A.; Bergandi, L.; Alotto, D.; Castagnoli, C.; Silvagno, F. Vitamin D Receptor Is Necessary for Mitochondrial Function and Cell Health. Int. J. Mol. Sci. 2018, 19, 1672. [CrossRef]

176. Consiglio, M.; Viano, M.; Casarin, S.; Castagnoli, C.; Pescarmona, G.; Silvagno, F. Mitochondrial and lipogenic effects of vitamin D on differentiating and proliferating human keratinocytes. Exp. Dermatol. 2015, 24, 748-753. [CrossRef] 
177. Sun, X.; Zemel, M.B. 1 $\alpha, 25$-Dihydroxyvitamin $\mathrm{D}_{3}$ Modulation of Adipocyte Reactive Oxygen Species Production. Obesity 2007, 15, 1944-1953. [CrossRef]

178. Berridge, M.J. Vitamin D cell signalling in health and disease. Biochem. Biophys. Res. Commun. 2015, 460, 53-71. [CrossRef]

179. Dong, J.; Wong, S.L.; Lau, C.W.; Lee, H.K.; Ng, C.F.; Zhang, L.; Yao, X.; Chen, Z.Y.; Vanhoutte, P.M.; Huang, Y. Calcitriol protects renovascular function in hypertension by down-regulating angiotensin II type 1 receptors and reducing oxidative stress. Eur. Heart J. 2012, 33, 2980-2990. [CrossRef]

180. Briones, T.L.; Darwish, H. Retraction notice to “Decrease in age-related tau hyperphosphorylation and cognitive improvement following vitamin D supplementation are associated with modulation of brain energy metabolism and redox state". Neuroscience 2014, 262, 143-155. [CrossRef]

181. Garcion, E.; Sindji, L.; Leblondel, G.; Brachet, P.; Darcy, F. 1,25-Dihydroxyvitamin $D_{3}$ Regulates the Synthesis of $\gamma$-Glutamyl Transpeptidase and Glutathione Levels in Rat Primary Astrocytes. J. Neurochem. 1999, 73, 859-866. [CrossRef]

182. Bao, B.-Y.; Ting, H.-J.; Hsu, J.-W.; Lee, Y.-F. Protective role of $1 \alpha$, 25 -dihydroxyvitamin $\mathrm{D}_{3}$ against oxidative stress in nonmalignant human prostate epithelial cells. Int. J. Cancer 2008, 122, 2699-2706. [CrossRef]

183. Jain, S.K.; Micinski, D. Vitamin D upregulates glutamate cysteine ligase and glutathione reductase, and GSH formation, and decreases ROS and MCP-1 and IL-8 secretion in high-glucose exposed U937 monocytes. Biochem. Biophys. Res. Commun. 2013, 437, 7-11. [CrossRef]

184. Loh, M.; Zhou, L.; Ng, H.K.; Chambers, J.C. Epigenetic disturbances in obesity and diabetes: Epidemiological and functional insights. Mol. Metab. 2019, 27, S33-S41. [CrossRef]

185. Wahl, S.; Drong, A.; Lehne, B.; Loh, M.; Scott, W.R.; Kunze, S.; Tsai, P.-C.; Ried, J.S.; Zhang, W.; Yang, Y.; et al. Epigenome-wide association study of body mass index, and the adverse outcomes of adiposity. Nature 2017, 541, 81-86. [CrossRef]

186. Pereira, F.; Barbáchano, A.; Singh, P.K.; Campbell, M.J.; Muñoz, A.; Larriba, M.J. Vitamin D has wide regulatory effects on histone demethylase genes. Cell Cycle 2012, 11, 1081-1089. [CrossRef]

187. Wamberg, L.; Christiansen, T.; Paulsen, S.K.; Fisker, S.; Rask, P.; Rejnmark, L.; Richelsen, B.; Pedersen, S.B. Expression of vitamin D-metabolizing enzymes in human adipose tissue-The effect of obesity and diet-induced weight loss. Int. J. Obes. 2013, 37, 651-657. [CrossRef]

188. Narvaez, C.J.; Simmons, K.M.; Brunton, J.; Salinero, A.; Chittur, S.V.; Welsh, J.E. Induction of STEAP4 correlates with 1,25-dihydroxyvitamin $\mathrm{D}_{3}$ stimulation of adipogenesis in mesenchymal progenitor cells derived from human adipose tissue. J. Cell. Physiol. 2013, 228, 2024-2036. [CrossRef]

189. Chang, E.; Kim, Y. Vitamin D decreases adipocyte lipid storage and increases NAD-SIRT1 pathway in 3T3-L1 adipocytes. Nutrition 2016, 32, 702-708. [CrossRef]

190. Nimitphong, H.; Holick, M.F.; Fried, S.K.; Lee, M.-J. 25-Hydroxyvitamin $D_{3}$ and 1,25-Dihydroxyvitamin $D_{3}$ Promote the Differentiation of Human Subcutaneous Preadipocytes. PLoS ONE 2012, 7, e52171. [CrossRef]

191. Ding, C.; Wilding, J.P.H.; Bing, C. 1,25-dihydroxyvitamin $D_{3}$ Protects against Macrophage-Induced Activation of NFKB and MAPK Signalling and Chemokine Release in Human Adipocytes. PLoS ONE 2013, 8, e61707. [CrossRef]

192. Sun, X.; Morris, K.L.; Zemel, M.B. Role of Calcitriol and Cortisol on Human Adipocyte Proliferation and Oxidative and Inflammatory Stress: A Microarray Study. LFG 2008, 1, 30-48. [CrossRef] [PubMed]

193. Shi, H.; Norman, A.W.; Okamura, W.H.; Sen, A.; Zemel, M.B. 1alpha, 25-dihydroxyvitamin $\mathrm{D}_{3}$ inhibits uncoupling protein 2 expression in human adipocytes. FASEB J. 2002, 16, 1808-1810. [CrossRef] [PubMed]

194. Xue, B.; Greenberg, A.G.; Kraemer, F.B.; Zemel, M.B. Mechanism of intracellular calcium ([Ca $\left.{ }^{2+}\right]$ i) inhibition of lipolysis in human adipocytes. FASEB J. 2001, 15, 2527-2529. [CrossRef]

195. Shi, H.; Norman, A.W.; Okamura, W.H.; Sen, A.; Zemel, M.B. 1alpha, 25-Dihydroxyvitamin $\mathrm{D}_{3}$ modulates human adipocyte metabolism via nongenomic action. FASEB J. 2001, 15, 2751-2753. [CrossRef]

196. Larrick, B.M.; Kim, K.-H.; Donkin, S.S.; Teegarden, D. 1,25-Dihydroxyvitamin D regulates lipid metabolism and glucose utilization in differentiated 3T3-L1 adipocytes. Nutr. Res. 2018, 58, 72-83. [CrossRef] [PubMed]

197. Silvagno, F.; Pescarmona, G. Spotlight on vitamin D receptor, lipid metabolism and mitochondria: Some preliminary emerging issues. Mol. Cell. Endocrinol. 2017, 450, 24-31. [CrossRef]

198. Kang, E.-J.; Lee, J.-E.; An, S.-M.; Lee, J.H.; Kwon, H.S.; Kim, B.C.; Kim, S.J.; Kim, J.M.; Hwang, D.Y.; Jung, Y.-J.; et al. The effects of vitamin $\mathrm{D}_{3}$ on lipogenesis in the liver and adipose tissue of pregnant rats. Int. J. Mol. Med. 2015, 36, 1151-1158. [CrossRef] 
199. Blumberg, J.M.; Tzameli, I.; Astapova, I.; Lam, F.S.; Flier, J.S.; Hollenberg, A.N. Complex Role of the Vitamin D Receptor and Its Ligand in Adipogenesis in 3T3-L1 Cells. J. Biol. Chem. 2006, 281, 11205-11213. [CrossRef]

200. Kong, J.; Li, Y.C. Molecular mechanism of 1,25-dihydroxyvitamin $\mathrm{D}_{3}$ inhibition of adipogenesis in 3T3-L1 cells. Am. J. Physiol.-Endocrinol. Metab. 2006, 290, E916-E924. [CrossRef]

201. Ross, S.E.; Hemati, N.; Longo, K.A.; Bennett, C.N.; Lucas, P.C.; Erickson, R.L.; MacDougald, O.A. Inhibition of Adipogenesis by Wnt Signaling. Science 2000, 289, 950-953. [CrossRef]

202. Sakuma, S.; Fujisawa, J.; Sumida, M.; Tanigawa, M.; Inoda, R.; Sujihera, T.; Kohda, T.; Fujimoto, Y. The involvement of mitogen-activated protein kinases in the 1 $\alpha, 25$-dihydroxy-cholecalciferol-induced inhibition of adipocyte differentiation in vitro. J. Nutr. Sci. Vitaminol. 2012, 58, 1-8. [CrossRef]

203. Lee, H.; Bae, S.; Yoon, Y. Anti-adipogenic effects of 1,25-dihydroxyvitamin $D_{3}$ are mediated by the maintenance of the wingless-type MMTV integration site/ß-catenin pathway. Int. J. Mol. Med. 2012, 30, 1219-1224. [CrossRef]

204. Cianferotti, L.; Demay, M.B. VDR-mediated inhibition of DKK1 and SFRP2 suppresses adipogenic differentiation of murine bone marrow stromal cells. J. Cell. Biochem. 2007, 101, 80-88. [CrossRef]

205. Mahajan, A.; Stahl, C.H. Dihydroxy-cholecalciferol stimulates adipocytic differentiation of porcine mesenchymal stem cells. J. Nutr. Biochem. 2009, 20, 512-520. [CrossRef]

206. Sergeev, I.N. 1,25-Dihydroxyvitamin $\mathrm{D}_{3}$ induces $\mathrm{Ca}^{2+}$-mediated apoptosis in adipocytes via activation of calpain and caspase-12. Biochem. Biophys. Res. Commun. 2009, 384, 18-21. [CrossRef]

207. Sergeev, I.N. Vitamin D Status and Vitamin D-Dependent Apoptosis in Obesity. Nutrients 2020, $12,1392$. [CrossRef]

208. Sergeev, I.N. 1,25-Dihydroxyvitamin $\mathrm{D}_{3}$ and type 2 diabetes: $\mathrm{Ca}^{2+}$-dependent molecular mechanisms and the role of vitamin D status. Horm. Mol. Biol. Clin. Investig. 2016, 26, 61-65. [CrossRef]

209. Sun, X.; Zemel, M.B. Role of uncoupling protein 2 (UCP2) expression and 1alpha, 25-dihydroxyvitamin $D_{3}$ in modulating adipocyte apoptosis. FASEB J. 2004, 18, 1430-1432. [CrossRef]

210. Zemel, M.B.; Sun, X. Calcitriol and energy metabolism. Nutr. Rev. 2008, 66, S139-S146. [CrossRef]

211. Sergeev, I.N.; Aljutaily, T.; Walton, G.; Huarte, E. Effects of Synbiotic Supplement on Human Gut Microbiota, Body Composition and Weight Loss in Obesity. Nutrients 2020, 12, 222. [CrossRef]

212. Park, J.E.; Pichiah, P.B.T.; Cha, Y.-S. Vitamin D and Metabolic Diseases: Growing Roles of Vitamin D. J. Obes. Metab. Syndr. 2018, 27, 223-232. [CrossRef] [PubMed]

213. Zhu, W.; Cai, D.; Wang, Y.; Lin, N.; Hu, Q.; Qi, Y.; Ma, S.; Amarasekara, S. Calcium plus vitamin $\mathrm{D}_{3}$ supplementation facilitated fat loss in overweight and obese college students with very-low calcium consumption: A randomized controlled trial. Nutr. J. 2013, 12, 8. [CrossRef] [PubMed]

214. Sergeev, I.N.; Song, Q. High vitamin D and calcium intakes reduce diet-induced obesity in mice by increasing adipose tissue apoptosis. Mol. Nutr. Food Res. 2014, 58, 1342-1348. [CrossRef]

215. Ping-Delfos, W.C.S.; Soares, M. Diet induced thermogenesis, fat oxidation and food intake following sequential meals: Influence of calcium and vitamin D. Clin. Nutr. 2011, 30, 376-383. [CrossRef]

216. Wong, K.E.; Szeto, F.L.; Zhang, W.; Ye, H.; Kong, J.; Zhang, Z.; Sun, X.J.; Li, Y.C. Involvement of the vitamin D receptor in energy metabolism: Regulation of uncoupling proteins. Am. J. Physiol. Endocrinol. Metab. 2009, 296, E820-E828. [CrossRef]

217. Trayhurn, P. Hypoxia and adipose tissue function and dysfunction in obesity. Physiol. Rev. 2013, 93, 1-21. [CrossRef]

218. Goossens, G.H. The role of adipose tissue dysfunction in the pathogenesis of obesity-related insulin resistance. Physiol. Behav. 2008, 94, 206-218. [CrossRef]

219. Vlasova, M.; Purhonen, A.K.; Jarvelin, M.R.; Rodilla, E.; Pascual, J.; Herzig, K.H. Role of adipokines in obesity-associated hypertension. Acta Physiol. 2010, 200, 107-127. [CrossRef]

220. Wellen, K.E.; Hotamisligil, G.S. Obesity-induced inflammatory changes in adipose tissue. J. Clin. Investig. 2003, 112, 1785-1788. [CrossRef]

221. Maury, E.; Brichard, S.M. Adipokine dysregulation, adipose tissue inflammation and metabolic syndrome. Mol. Cell. Endocrinol. 2010, 314,1-16. [CrossRef]

222. Liu, P.T.; Stenger, S.; Li, H.; Wenzel, L.; Tan, B.H.; Krutzik, S.R.; Ochoa, M.T.; Schauber, J.; Wu, K.; Meinken, C.; et al. Toll-like receptor triggering of a vitamin D-mediated human antimicrobial response. Science 2006, 311, 1770-1773. [CrossRef] [PubMed] 
223. Gautam, D.; Han, S.-J.; Hamdan, F.F.; Jeon, J.; Li, B.; Li, J.H.; Cui, Y.; Mears, D.; Lu, H.; Deng, C.; et al. A critical role for $\beta$ cell M3 muscarinic acetylcholine receptors in regulating insulin release and blood glucose homeostasis in vivo. Cell Metab. 2006, 3, 449-461. [CrossRef] [PubMed]

224. Molina, J.; Rodriguez-Diaz, R.; Fachado, A.; Jacques-Silva, M.C.; Berggren, P.-O.; Caicedo, A. Control of Insulin Secretion by Cholinergic Signaling in the Human Pancreatic Islet. Diabetes 2014, 63, 2714-2726. [CrossRef] [PubMed]

225. Crook, M. Type 2 diabetes mellitus: A disease of the innate immune system? An update. Diabet. Med. 2004, 21, 203-207. [CrossRef]

226. Hotamisligil, G.S.; Peraldi, P.; Budavari, A.; Ellis, R.; White, M.F.; Spiegelman, B.M. IRS-1-mediated inhibition of insulin receptor tyrosine kinase activity in TNF-alpha- and obesity-induced insulin resistance. Science 1996, 271, 665-668. [CrossRef]

227. Hotamisligil, G.S.; Shargill, N.S.; Spiegelman, B.M. Adipose expression of tumor necrosis factor-alpha: Direct role in obesity-linked insulin resistance. Science 1993, 259, 87-91. [CrossRef]

228. Folli, F.; Saad, M.J.; Backer, J.M.; Kahn, C.R. Regulation of phosphatidylinositol 3-kinase activity in liver and muscle of animal models of insulin-resistant and insulin-deficient diabetes mellitus. J. Clin. Investig. 1993, 92, 1787-1794. [CrossRef]

229. Gao, D.; Trayhurn, P.; Bing, C. 1,25-Dihydroxyvitamin $\mathrm{D}_{3}$ inhibits the cytokine-induced secretion of MCP-1 and reduces monocyte recruitment by human preadipocytes. Int. J. Obes. 2013, 37, 357-365. [CrossRef]

230. Velloso, L.A.; Folli, F.; Sun, X.J.; White, M.F.; Saad, M.J.; Kahn, C.R. Cross-talk between the insulin and angiotensin signaling systems. Proc. Natl. Acad. Sci. USA 1996, 93, 12490-12495. [CrossRef]

231. Li, B.; Baylink, D.J.; Deb, C.; Zannetti, C.; Rajaallah, F.; Xing, W.; Walter, M.H.; Lau, K.-H.W.; Qin, X. 1,25-Dihydroxyvitamin $\mathrm{D}_{3}$ suppresses TLR8 expression and TLR8-mediated inflammatory responses in monocytes in vitro and experimental autoimmune encephalomyelitis in vivo. PLoS ONE 2013, 8, e58808. [CrossRef]

232. Hotamisligil, G.S. Inflammation and metabolic disorders. Nature 2006, 444, 860-867. [CrossRef] [PubMed]

233. Marcotorchino, J.; Gouranton, E.; Romier, B.; Tourniaire, F.; Astier, J.; Malezet, C.; Amiot, M.-J.; Landrier, J.-F. Vitamin D reduces the inflammatory response and restores glucose uptake in adipocytes. Mol. Nutr. Food Res. 2012, 56, 1771-1782. [CrossRef] [PubMed]

234. Ching, S.; Kashinkunti, S.; Niehaus, M.D.; Zinser, G.M. Mammary adipocytes bioactivate 25-hydroxyvitamin $\mathrm{D}_{3}$ and signal via vitamin $\mathrm{D}_{3}$ receptor, modulating mammary epithelial cell growth. J. Cell. Biochem. 2011, 112, 3393-3405. [CrossRef] [PubMed]

235. Li, J.; Byrne, M.E.; Chang, E.; Jiang, Y.; Donkin, S.S.; Buhman, K.K.; Burgess, J.R.; Teegarden, D.

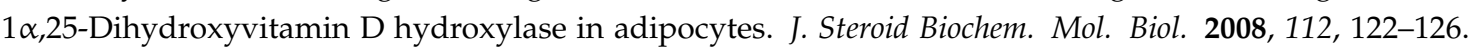
[CrossRef]

236. Lira, F.S.; Rosa, J.C.; Cunha, C.A.; Ribeiro, E.B.; do Nascimento, C.O.; Oyama, L.M.; Mota, J.F. Supplementing alpha-tocopherol (vitamin $\mathrm{E}$ ) and vitamin $\mathrm{D}_{3}$ in high fat diet decrease IL-6 production in murine epididymal adipose tissue and 3T3-L1 adipocytes following LPS stimulation. Lipids Health Dis. 2011, 10, 37. [CrossRef]

237. Mutt, S.J.; Hyppönen, E.; Saarnio, J.; Järvelin, M.-R.; Herzig, K.-H. Vitamin D and adipose tissue-More than storage. Front. Physiol. 2014, 5, 228. [CrossRef]

238. Chang, E.; Kim, Y. Vitamin D Insufficiency Exacerbates Adipose Tissue Macrophage Infiltration and Decreases AMPK/SIRT1 Activity in Obese Rats. Nutrients 2017, 9, 338. [CrossRef]

239. Karkeni, E.; Bonnet, L.; Marcotorchino, J.; Tourniaire, F.; Astier, J.; Ye, J.; Landrier, J.-F. Vitamin D limits inflammation-linked microRNA expression in adipocytes in vitro and in vivo: A new mechanism for the regulation of inflammation by vitamin D. Epigenetics 2018, 13, 156-162. [CrossRef]

240. Mutt, S.J.; Karhu, T.; Lehtonen, S.; Lehenkari, P.; Carlberg, C.; Saarnio, J.; Sebert, S.; Hyppönen, E.; Järvelin, M.-R.; Herzig, K.-H. Inhibition of cytokine secretion from adipocytes by 1,25-dihydroxyvitamin $\mathrm{D}_{3}$ via the NF-кB pathway. FASEB J. 2012, 26, 4400-4407. [CrossRef]

241. Frühbeck, G.; Aguado, M.; Martínez, J.A. In vitro lipolytic effect of leptin on mouse adipocytes: Evidence for a possible autocrine/paracrine role of leptin. Biochem. Biophys. Res. Commun. 1997, 240, 590-594. [CrossRef]

242. Frühbeck, G.; Aguado, M.; Gómez-Ambrosi, J.; Martínez, J.A. Lipolytic effect of in vivo leptin administration on adipocytes of lean and ob/ob mice, but not db/db mice. Biochem. Biophys. Res. Commun. 1998, 250, $99-102$. [CrossRef] 
243. Zhu, J.; Bing, C.; Wilding, J.P.H. Vitamin D receptor ligands attenuate the inflammatory profile of IL-1 $\beta$-stimulated human white preadipocytes via modulating the NF- $\mathrm{kB}$ and unfolded protein response pathways. Biochem. Biophys. Res. Commun. 2018, 503, 1049-1056. [CrossRef]

244. Tourniaire, F.; Romier-Crouzet, B.; Lee, J.H.; Marcotorchino, J.; Gouranton, E.; Salles, J.; Malezet, C.; Astier, J.; Darmon, P.; Blouin, E.; et al. Chemokine Expression in Inflamed Adipose Tissue Is Mainly Mediated by NF-кB. PLoS ONE 2013, 8, e66515. [CrossRef]

245. Cannell, J.J.; Grant, W.B.; Holick, M.F. Vitamin D and inflammation. Derm.-Endocrinol. 2014, 6, e983401. [CrossRef]

246. Wamberg, L.; Cullberg, K.B.; Rejnmark, L.; Richelsen, B.; Pedersen, S.B. Investigations of the anti-inflammatory effects of vitamin $\mathrm{D}$ in adipose tissue: Results from an in vitro study and a randomized controlled trial. Horm. Metab. Res. 2013, 45, 456-462. [CrossRef] [PubMed]

247. García-Bailo, B.; Roke, K.; Mutch, D.M.; El-Sohemy, A.; Badawi, A. Association between circulating ascorbic acid, $\alpha$-tocopherol, 25-hydroxyvitamin D, and plasma cytokine concentrations in young adults: A cross-sectional study. Nutr. Metab. 2012, 9, 102. [CrossRef] [PubMed]

248. Khoo, A.-L.; Chai, L.Y.A.; Koenen, H.J.P.M.; Kullberg, B.-J.; Joosten, I.; van der Ven, A.J.A.M.; Netea, M.G. 1,25-dihydroxyvitamin $\mathrm{D}_{3}$ modulates cytokine production induced by Candida albicans: Impact of seasonal variation of immune responses. J. Infect. Dis. 2011, 203, 122-130. [CrossRef] [PubMed]

249. Schleithoff, S.S.; Zittermann, A.; Tenderich, G.; Berthold, H.K.; Stehle, P.; Koerfer, R. Vitamin D supplementation improves cytokine profiles in patients with congestive heart failure: A double-blind, randomized, placebo-controlled trial. Am. J. Clin. Nutr. 2006, 83, 754-759. [CrossRef] [PubMed]

250. Petchey, W.G.; Johnson, D.W.; Isbel, N.M. Shining D' light on chronic kidney disease: Mechanisms that may underpin the cardiovascular benefit of vitamin D. Nephrology 2011, 16, 351-367. [CrossRef] [PubMed]

251. Kong, J.; Chen, Y.; Zhu, G.; Zhao, Q.; Li, Y.C. 1,25-Dihydroxyvitamin $\mathrm{D}_{3}$ upregulates leptin expression in mouse adipose tissue. J. Endocrinol. 2013, 216, 265-271. [CrossRef] [PubMed]

252. Roy, P.; Nadeau, M.; Valle, M.; Bellmann, K.; Marette, A.; Tchernof, A.; Gagnon, C. Vitamin D reduces LPS-induced cytokine release in omental adipose tissue of women but not men. Steroids 2015, 104, 65-71. [CrossRef]

253. Walker, G.E.; Ricotti, R.; Roccio, M.; Moia, S.; Bellone, S.; Prodam, F.; Bona, G. Pediatric obesity and vitamin D deficiency: A proteomic approach identifies multimeric adiponectin as a key link between these conditions. PLoS ONE 2014, 9, e83685. [CrossRef] [PubMed]

254. Schwartz, M.W.; Woods, S.C.; Porte, D.; Seeley, R.J.; Baskin, D.G. Central nervous system control of food intake. Nature 2000, 404, 661-671. [CrossRef] [PubMed]

255. Koszowska, A.U.; Nowak, J.; Dittfeld, A.; Brończyk-Puzoń, A.; Kulpok, A.; Zubelewicz-Szkodzińska, B. Obesity, adipose tissue function and the role of vitamin D. Cent. Eur. J. Immunol. 2014, 39, 260-264. [CrossRef] [PubMed]

256. Mantzoros, C.S. The role of leptin in human obesity and disease: A review of current evidence. Ann. Intern. Med. 1999, 130, 671-680. [CrossRef]

257. Wasiluk, D.; Stefanska, E.; Ostrowska, L.; Serwin, A.B.; Klepacki, A.; Chodynicka, B. Nutritive value of daily food rations of patients with psoriasis vulgaris: A preliminary report. Adv. Dermatol. Allergol. 2012, 29, 348-355. [CrossRef]

258. Narvaez, C.J.; Matthews, D.; Broun, E.; Chan, M.; Welsh, J. Lean Phenotype and Resistance to Diet-Induced Obesity in Vitamin D Receptor Knockout Mice Correlates with Induction of Uncoupling Protein-1 in White Adipose Tissue. Endocrinology 2009, 150, 651-661. [CrossRef]

259. Kaneko, I.; Sabir, M.S.; Dussik, C.M.; Whitfield, G.K.; Karrys, A.; Hsieh, J.-C.; Haussler, M.R.; Meyer, M.B.; Pike, J.W.; Jurutka, P.W. 1,25-Dihydroxyvitamin D regulates expression of the tryptophan hydroxylase 2 and leptin genes: Implication for behavioral influences of vitamin D. FASEB J. 2015, 29, 4023-4035. [CrossRef]

260. Tsuji, K.; Maeda, T.; Kawane, T.; Matsunuma, A.; Horiuchi, N. Leptin stimulates fibroblast growth factor 23 expression in bone and suppresses renal $1 \alpha, 25$-dihydroxyvitamin $\mathrm{D}_{3}$ synthesis in leptin-deficient ob/ob Mice. J. Bone Miner. Res. 2010, 25, 1711-1723. [CrossRef]

261. Bouillon, R.; Carmeliet, G.; Lieben, L.; Watanabe, M.; Perino, A.; Auwerx, J.; Schoonjans, K.; Verstuyf, A. Vitamin D and energy homeostasis-Of mice and men. Nat. Rev. Endocrinol. 2014, 10, 79-87. [CrossRef]

262. Scherer, P.E.; Williams, S.; Fogliano, M.; Baldini, G.; Lodish, H.F. A Novel Serum Protein Similar to C1q, Produced Exclusively in Adipocytes. J. Biol. Chem. 1995, 270, 26746-26749. [CrossRef] 
263. Chandran, M.; Phillips, S.A.; Ciaraldi, T.; Henry, R.R. Adiponectin: More than just another fat cell hormone? Diabetes Care 2003, 26, 2442-2450. [CrossRef] [PubMed]

264. Neyestani, T.R.; Nikooyeh, B.; Alavi-Majd, H.; Shariatzadeh, N.; Kalayi, A.; Tayebinejad, N.; Heravifard, S.; Salekzamani, S.; Zahedirad, M. Improvement of Vitamin D Status via Daily Intake of Fortified Yogurt Drink Either with or without Extra Calcium Ameliorates Systemic Inflammatory Biomarkers, including Adipokines, in the Subjects with Type 2 Diabetes. J. Clin. Endocrinol. Metab. 2012, 97, 2005-2011. [CrossRef]

265. Sun, X.; Zemel, M.B. Calcium and 1,25-Dihydroxyvitamin $\mathrm{D}_{3}$ Regulation of Adipokine Expression. Obesity 2007, 15, 340-348. [CrossRef] [PubMed]

266. Lorente-Cebrián, S.; Eriksson, A.; Dunlop, T.; Mejhert, N.; Dahlman, I.; Åström, G.; Sjölin, E.; Wåhlén, K.; Carlberg, C.; Laurencikiene, J.; et al. Differential effects of 1 $1 \alpha, 25$-dihydroxycholecalciferol on MCP-1 and adiponectin production in human white adipocytes. Eur. J. Nutr. 2012, 51, 335-342. [CrossRef] [PubMed]

267. Gilsanz, V.; Kremer, A.; Mo, A.O.; Wren, T.A.L.; Kremer, R. Vitamin D status and its relation to muscle mass and muscle fat in young women. J. Clin. Endocrinol. Metab. 2010, 95, 1595-1601. [CrossRef]

268. Tamilselvan, B.; Seshadri, K.G.; Venkatraman, G. Role of vitamin D on the expression of glucose transporters in L6 myotubes. Indian J. Endocrinol. Metab. 2013, 17, S326-S328. [CrossRef] [PubMed]

269. Salles, J.; Chanet, A.; Giraudet, C.; Patrac, V.; Pierre, P.; Jourdan, M.; Luiking, Y.C.; Verlaan, S.; Migné, C.; Boirie, Y.; et al. $1,25(\mathrm{OH})_{2}$-vitamin $\mathrm{D}_{3}$ enhances the stimulating effect of leucine and insulin on protein synthesis rate through $\mathrm{Akt} / \mathrm{PKB}$ and mTOR mediated pathways in murine $\mathrm{C} 2 \mathrm{C} 12$ skeletal myotubes. Mol. Nutr. Food Res. 2013, 57, 2137-2146. [CrossRef]

270. Girgis, C.M.; Clifton-Bligh, R.J.; Hamrick, M.W.; Holick, M.F.; Gunton, J.E. The roles of vitamin D in skeletal muscle: Form, function, and metabolism. Endocr. Rev. 2013, 34, 33-83. [CrossRef] [PubMed]

271. Zhou, Q.G.; Hou, F.F.; Guo, Z.J.; Liang, M.; Wang, G.B.; Zhang, X. 1,25-Dihydroxyvitamin D improved the free fatty-acid-induced insulin resistance in cultured C2C12 cells. Diabetes Metab. Res. Rev. 2008, 24, 459-464. [CrossRef]

272. Jefferson, G.E.; Schnell, D.M.; Thomas, D.T.; Bollinger, L.M. Calcitriol concomitantly enhances insulin sensitivity and alters myocellular lipid partitioning in high fat-treated skeletal muscle cells. J. Physiol. Biochem. 2017, 73, 613-621. [CrossRef] [PubMed]

273. Ryan, Z.C.; Craig, T.A.; Folmes, C.D.; Wang, X.; Lanza, I.R.; Schaible, N.S.; Salisbury, J.L.; Nair, K.S.; Terzic, A.; Sieck, G.C.; et al. 1 $\alpha$,25-Dihydroxyvitamin $\mathrm{D}_{3}$ Regulates Mitochondrial Oxygen Consumption and Dynamics in Human Skeletal Muscle Cells. J. Biol. Chem. 2016, 291, 1514-1528. [CrossRef]

274. Asrih, M.; Jornayvaz, F.R. Inflammation as a potential link between nonalcoholic fatty liver disease and insulin resistance. J. Endocrinol. 2013, 218, R25-R36. [CrossRef] [PubMed]

275. Kong, M.; Zhu, L.; Bai, L.; Zhang, X.; Chen, Y.; Liu, S.; Zheng, S.; Pandol, S.J.; Han, Y.-P.; Duan, Z. Vitamin D deficiency promotes nonalcoholic steatohepatitis through impaired enterohepatic circulation in animal model. Am. J. Physiol. Gastrointest. Liver Physiol. 2014, 307, G883-G893. [CrossRef]

276. Li, R.; Guo, E.; Yang, J.; Li, A.; Yang, Y.; Liu, S.; Liu, A.; Jiang, X. 1,25(OH) ${ }_{2} \mathrm{D}_{3}$ attenuates hepatic steatosis by inducing autophagy in mice. Obesity 2017, 25, 561-571. [CrossRef] [PubMed]

277. Long, Y.C.; Zierath, J.R. AMP-activated protein kinase signaling in metabolic regulation. J. Clin. Investig. 2006, 116, 1776-1783. [CrossRef] [PubMed]

278. Barthel, A.; Schmoll, D.; Krüger, K.-D.; Roth, R.A.; Joost, H.-G. Regulation of the forkhead transcription factor FKHR (FOXO1a) by glucose starvation and AICAR, an activator of AMP-activated protein kinase. Endocrinology 2002, 143, 3183-3186. [CrossRef]

279. Li, Y.; Xu, S.; Giles, A.; Nakamura, K.; Lee, J.W.; Hou, X.; Donmez, G.; Li, J.; Luo, Z.; Walsh, K.; et al. Hepatic overexpression of SIRT1 in mice attenuates endoplasmic reticulum stress and insulin resistance in the liver. FASEB J. 2011, 25, 1664-1679. [CrossRef]

280. Kamagate, A.; Kim, D.H.; Zhang, T.; Slusher, S.; Gramignoli, R.; Strom, S.C.; Bertera, S.; Ringquist, S.; Dong, H.H. FoxO1 links hepatic insulin action to endoplasmic reticulum stress. Endocrinology 2010, 151, 3521-3535. [CrossRef]

281. Nelson, J.E.; Roth, C.L.; Wilson, L.A.; Yates, K.P.; Aouizerat, B.; Morgan-Stevenson, V.; Whalen, E.; Hoofnagle, A.; Mason, M.; Gersuk, V.; et al. Vitamin D Deficiency Is Associated With Increased Risk of Non-alcoholic Steatohepatitis in Adults With Non-alcoholic Fatty Liver Disease: Possible Role for MAPK and NF-кB? Am. J. Gastroenterol. 2016, 111, 852-863. [CrossRef] 
282. Bril, F.; Maximos, M.; Portillo-Sanchez, P.; Biernacki, D.; Lomonaco, R.; Subbarayan, S.; Correa, M.; Lo, M.; Suman, A.; Cusi, K. Relationship of vitamin D with insulin resistance and disease severity in non-alcoholic steatohepatitis. J. Hepatol. 2015, 62, 405-411. [CrossRef] [PubMed]

283. Lemire, J. 1,25-Dihydroxyvitamin $\mathrm{D}_{3}$-A hormone with immunomodulatory properties. Z. Rheumatol. 2000, 59 (Suppl. S1), 24-27. [CrossRef] [PubMed]

284. González-Molero, I.; Rojo-Martínez, G.; Morcillo, S.; Gutierrez, C.; Rubio, E.; Pérez-Valero, V.; Esteva, I.; Ruiz de Adana, M.S.; Almaraz, M.C.; Colomo, N.; et al. Hypovitaminosis D and incidence of obesity: A prospective study. Eur. J. Clin. Nutr. 2013, 67, 680-682. [CrossRef] [PubMed]

285. Landrier, J.-F.; Karkeni, E.; Marcotorchino, J.; Bonnet, L.; Tourniaire, F. Vitamin D modulates adipose tissue biology: Possible consequences for obesity? Proc. Nutr. Soc. 2016, 75, 38-46. [CrossRef]

286. Barragan, M.; Good, M.; Kolls, J.K. Regulation of Dendritic Cell Function by Vitamin D. Nutrients 2015, 7, 8127-8151. [CrossRef]

287. Giulietti, A.; van Etten, E.; Overbergh, L.; Stoffels, K.; Bouillon, R.; Mathieu, C. Monocytes from type 2 diabetic patients have a pro-inflammatory profile. 1,25-Dihydroxyvitamin $\mathrm{D}(3)$ works as anti-inflammatory. Diabetes Res. Clin. Pract. 2007, 77, 47-57. [CrossRef]

288. Neve, A.; Corrado, A.; Cantatore, F.P. Immunomodulatory effects of vitamin D in peripheral blood monocyte-derived macrophages from patients with rheumatoid arthritis. Clin. Exp. Med. 2014, 14, 275-283. [CrossRef]

289. Sloka, S.; Silva, C.; Wang, J.; Yong, V.W. Predominance of Th2 polarization by vitamin D through a STAT6-dependent mechanism. J. Neuroinflamm. 2011, 8, 56. [CrossRef]

290. Morin, S.O.; Poggi, M.; Alessi, M.-C.; Landrier, J.-F.; Nunès, J.A. Modulation of T Cell Activation in Obesity. Antioxid. Redox Signal. 2016, 26, 489-500. [CrossRef]

291. Zeng, H.; Chi, H. Metabolic control of regulatory T cell development and function. Trends Immunol. 2015, 36, 3-12. [CrossRef]

292. Olefsky, J.M.; Glass, C.K. Macrophages, Inflammation, and Insulin Resistance. Annu. Rev. Physiol. 2010, 72, 219-246. [CrossRef] [PubMed]

293. Bapat, S.P.; Myoung Suh, J.; Fang, S.; Liu, S.; Zhang, Y.; Cheng, A.; Zhou, C.; Liang, Y.; LeBlanc, M.; Liddle, C.; et al. Depletion of fat-resident $\mathrm{T}_{\text {reg }}$ cells prevents age-associated insulin resistance. Nature 2015, 528, 137-141. [CrossRef] [PubMed]

294. Mocanu, V.; Oboroceanu, T.; Zugun-Eloae, F. Current status in vitamin D and regulatory T cells-immunological implications. Med.-Surg. J. 2013, 117, 965-973.

295. Lynch, L. Adipose invariant natural killer T cells. Immunology 2014, 142, 337-346. [CrossRef] [PubMed] 